\title{
Methylene-Linked Bis-NHC Half-Sandwich Ruthenium Complexes: Binding of Small Molecules and Catalysis toward Ketone Transfer Hydrogenation
}

\author{
José Manuel Botubol-Ares, Safa Cordón-Ouahhabi, Zakaria Moutaoukil, Isidro G. Collado, \\ Manuel Jiménez-Tenorio,* M. Carmen Puerta, and Pedro Valerga
}

Cite This: Organometallics 2021, 40, 792-803

Read Online

ACCESS | Lلll Metrics \& More | 回 Article Recommendations | st Supporting Information

ABSTRACT: The complex $[\mathrm{Cp} * \mathrm{RuCl}(\mathrm{COD})]$ reacts with $\mathrm{LH}_{2} \mathrm{Cl}_{2}$ ( $\mathrm{L}=$ bis(3-methylimidazol-2-ylidene $)$ ) and $\mathrm{LiBu}^{n}$ in tetrahydrofuran at $65{ }^{\circ} \mathrm{C}$ furnishing the bis-carbene derivative $[\mathrm{Cp} * \mathrm{RuCl}(\mathrm{L})](2)$. This compound reacts with $\mathrm{NaBPh}_{4}$ in $\mathrm{MeOH}$ under dinitrogen to yield the labile dinitrogen-bridged complex $\left[\{\mathrm{Cp} * \mathrm{Ru}(\mathrm{L})\}_{2}(\mu\right.$ $\left.\left.\mathrm{N}_{2}\right)\right]\left[\mathrm{BPh}_{4}\right]_{2}$ (4). The dinitrogen ligand in 4 is readily replaced by a series of donor molecules leading to the corresponding cationic complexes $[\mathrm{Cp} * \mathrm{Ru}(\mathrm{X})(\mathrm{L})]\left[\mathrm{BPh}_{4}\right]\left(\mathrm{X}=\mathrm{MeCN} \mathbf{3}, \mathrm{H}_{2} \mathbf{6}, \mathrm{C}_{2} \mathrm{H}_{4} \mathbf{8 a}\right.$, $\left.\mathrm{CH}_{2} \mathrm{CHCOOMe} \mathbf{8 b}, \mathrm{CHPh} 9\right)$. Attempts to recrystallize 4 from $\mathrm{MeNO}_{2} / \mathrm{EtOH}$ solutions led to the isolation of the nitrosyl derivative $\left[\mathrm{Cp}^{*} \mathrm{Ru}(\mathrm{NO})(\mathrm{L})\right]\left[\mathrm{BPh}_{4}\right]_{2}(\mathbf{5})$, which was structurally characterized. The allenylidene complex $[\mathrm{Cp} * \mathrm{Ru}=\mathrm{C}=\mathrm{C}=$ $\left.\mathrm{CPh}_{2}(\mathrm{~L})\right]\left[\mathrm{BPh}_{4}\right](\mathbf{1 0})$ was also obtained, and it was prepared by

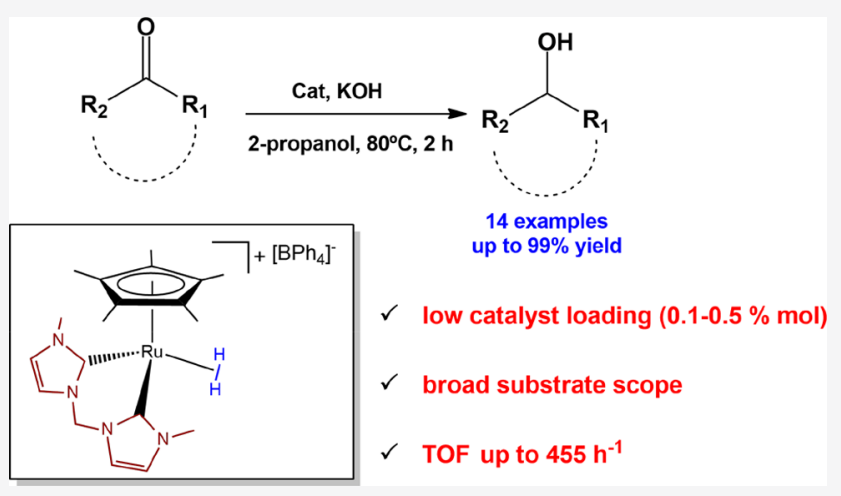
reaction of 2 with $\mathrm{HC} \equiv \mathrm{CC}(\mathrm{OH}) \mathrm{Ph}_{2}$ and $\mathrm{NaBPh}_{4}$ in $\mathrm{MeOH}$ at 60

${ }^{\circ} \mathrm{C}$. Complexes 3, 4, and 6 are efficient catalyst precursors for the transfer hydrogenation of a broad range of ketones. The dihydrogen complex 6 has proven particularly effective, reaching TOF values up to $455 \mathrm{~h}^{-1}$ at catalyst loadings of $0.1 \%$ mol, with a high functional group tolerance on the reduction of a broad scope of aryl and aliphatic ketones to yield the corresponding alcohols.

\section{INTRODUCTION}

The catalytic transfer hydrogenation (TH) of carbonyl groups to afford their corresponding alcohols is considered a useful synthetic tool to produce valuable building blocks for the pharmaceutical industry. ${ }^{1-3}$ This methodology has as an advantage the use of alcohols, ${ }^{4}$ water, ${ }^{5}$ or formic acid ${ }^{6}$ instead of molecular hydrogen or metal hydrides as sources of the hydrogen atoms transferred in the reaction. Catalytic TH using transition metal complexes has received a great deal of attention due to its selectivity, efficiency, safety, broad scope, and compatibility with Green Chemistry principles. Homogeneous complexes based on transition metals such as $\mathrm{Ir}^{1,7} \mathrm{Ru},{ }^{1,8}$ or $\mathrm{Rh}^{1,9}$ are often used as catalysts for $\mathrm{TH}{ }^{1}$ However, the development of more efficient and selective transfer hydrogenation catalysts are still in demand. Among them, ruthenium complexes possess higher activity, selectivity, and cheaper cost in comparison to those of rhodium or iridium. ${ }^{10}$

NHC ligands have been successfully used as ancillary ligands in the design and synthesis of homogeneous catalysts. ${ }^{11}$ These ligands are considered an alternative to phosphine ligands due to their stronger sigma-donor properties that confer a greater stability to the corresponding metallic complexes, and facilitate the modulation of their stereoelectronic properties. ${ }^{12}$ Chelation is a strategy used to stabilize the $\mathrm{M}-\mathrm{NHC}$ bond and provide more robust complexes with different topological properties, namely steric hindrance, bite angle, or fluxional behavior. ${ }^{13}$ In contrast to their monodentate counterparts, the chemistry of transition-metal complexes based on bis(NHC) ligands have been far less explored. ${ }^{14}$ Ruthenium(II)-NHC complexes have been recently used in a wide range of organic reactions ${ }^{15}$ including $\mathrm{TH}$ reactions. ${ }^{111 a, 16-18}$ However, the synthesis and catalytic application of their related hydrocarbon chain-linked bis(NHC) complexes is scarce in the literature and their potential synthetic applicability still needs to be studied. To the best of our knowledge, only a few reports have been described about the use of hydrocarbon chain-linked bis(NHC) complexes of ruthenium in $\mathrm{TH}$ of ketones ${ }^{19}$ and hydrogenation of olefins. ${ }^{20}$

Following the recent works carried out in our research group in the preparation of $\mathrm{TpRu}$ complexes bearing the methylene-

Received: January 26, 2021

Published: March 9, 2021 
linked bis(NHC) ligand bis(3-methylimidazol-2-ylidene)methane $(\mathbf{L}),{ }^{21}$ we focused our attention in the preparation of homologous pentamethylcyclopentadienyl ( $\mathrm{Cp} *)$ ruthenium complexes with the same ligand in order to compare the effect of the replacement of the supporting ligand $\mathrm{Tp}$ by $\mathrm{Cp}$ * on the reactivity of the metal center. We have now found that this modification enhances reactivity, and that several of the new complexes prepared in this way are efficient catalyst precursors for $\mathrm{TH}$ reactions of carbonyl groups.

\section{RESULTS AND DISCUSSION}

Synthesis of Complexes and Their Interaction with Small Molecules. The transmetalation reaction of silverNHC complexes is a well-known synthetic procedure for the introduction of NHC ligands into a system. ${ }^{12,13,22}$ We have successfully used this methodology for the preparation of $\mathrm{Ru}^{18,21,23}$ and $\mathrm{Ni}^{24}$ complexes. In particular, we prepared the complex $[\mathrm{TpRuCl}(\mathbf{L})]$ by reaction of $[\mathrm{TpRuCl}(\mathrm{COD})]$ with $\mathrm{L} \cdot \mathrm{Ag}_{2} \mathrm{Cl}_{2}$ in dichloroethane at $120{ }^{\circ} \mathrm{C}$ over $20 \mathrm{~h}^{21}$ In an attempt to synthesize the homologous complex bearing $\mathrm{Cp}^{*}$ instead of $\mathrm{Tp}$, we carried out the reaction of $[\mathrm{Cp} * \mathrm{RuCl}-$ (COD)] with $\mathrm{L} \cdot \mathrm{Ag}_{2} \mathrm{Cl}_{2}$ in dichloroethane at $130{ }^{\circ} \mathrm{C}$ over $18 \mathrm{~h}$. A cherry red microcrystalline product was obtained from this reaction. NMR spectroscopy showed that the compound was paramagnetic. Recrystallization from dichloromethane/petroleum ether yielded dark cherry red crystals. The X-ray structure analysis identified this product as the $\mathrm{Ru}^{\mathrm{III}}$ derivative $[\mathrm{Cp} * \mathrm{RuCl}(\mathbf{L})] \mathrm{Cl}(\mathbf{1})$. An ORTEP view of the complex cation $[\mathrm{Cp} * \mathrm{RuCl}(\mathbf{L})]^{+}$in $\mathbf{1}$ is shown in Figure 1 , together with the most relevant bond distances and angles.

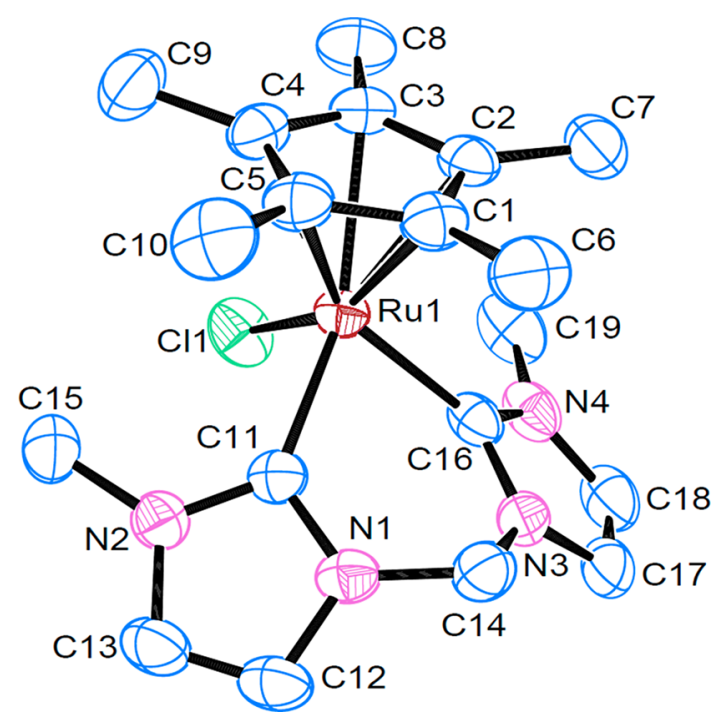

Figure 1. ORTEP drawing (50\% displacement ellipsoids, hydrogen atoms omitted) of $[\mathrm{Cp} * \operatorname{RuCl}(\mathbf{L})]^{+}$in $\mathbf{1}$. Selected bond lengths $(\AA)$ and angles (deg): $\mathrm{Ru}(1)-\mathrm{C}(11) 2.038(3), \mathrm{Ru}(1)-\mathrm{C}(16) 2.045(2)$, $\mathrm{Ru}(1)-\mathrm{Cl}(1)$ 2.3766(9), $\mathrm{Ru}(1)-\mathrm{C}(1)$ 2.284(3), $\mathrm{Ru}(1)-\mathrm{C}(2)$ 2.230(3), $\mathrm{Ru}(1)-\mathrm{C}(3)$ 2.183(3), $\mathrm{Ru}(1)-\mathrm{C}(4)$ 2.222(3), $\mathrm{Ru}(1)-$ $\mathrm{C}(5) 2.262(3) ; \mathrm{C}(11)-\mathrm{Ru}(1)-\mathrm{C}(16) 81.9(1)$.

The complex cation has a typical three-legged piano stool structure in which the ruthenium atom adopts a distorted pseudo-octahedral geometry. The bis-carbene chelating bite angle $\mathrm{C}(11)-\mathrm{Ru}(1)-\mathrm{C}(16)$ of $81.9(1)^{\circ}$ is slightly smaller than the typical values reported for this ligand, usually in the range $83.2-87.8^{\circ}, 21,25-27$ although values as small as $79.4^{\circ}$ have been reported. The average dihedral angle between the plane defined by the atoms $C(11)-R u(1)-C(16)$ and the imidazol rings of $35.65^{\circ}$ is slightly higher than the same angle observed for other pseudo-octahedral complexes containing the same ligand $\mathbf{L}$ (range $\left.19.7-32.1^{\circ}\right) .^{21,25-27}$ The $\mathrm{Ru}-\mathrm{C}$ distances for the NHC ligand are 2.038(3) and 2.045(2) $\AA$, typical for $\mathrm{Ru}-\mathrm{C} \sigma$-bonds, and indicative of an essentially symmetrical arrangement of the imidazolylidene rings. The $\mathrm{Ru}(1)-\mathrm{Cl}(1)$ bond distance of $2.3766(9) \AA$ is slightly shorter than the $\mathrm{Ru}-\mathrm{Cl}$ separations of 2.4436(11) and 2.389(2) $\AA$ reported for the chloro complexes $\left[\mathrm{TpRuCl}\left(\kappa^{2}-C, N\right.\right.$-picoly$\left.1{ }^{\mathrm{iPr}} \mathrm{I}\right)$ ] (picolyl- ${ }^{\mathrm{iPr}} \mathrm{I}=3$-isopropyl-1-(2-picolyl)imidazol-2-ylidene $)^{23}$ and $\left[(p\right.$-cymene $) \mathrm{RuCl}\left(\kappa^{2}-C, N\right.$-picolyl- $\left.\left.{ }^{\mathrm{Me}} \mathrm{I}\right)\right]\left[\mathrm{PF}_{6}\right]$ (picolyl- ${ }^{\mathrm{Me}} \mathrm{I}=3$-methyl-1-(2-picolyl)imidazol-2-ylidene), ${ }^{18}$ but in the range of $2.340-2.376 \AA$ observed for $\mathrm{Ru}-\mathrm{Cl}$ bond lengths in the complexes $[\mathrm{Cp} * \mathrm{RuCl}(\mathrm{NHC})](\mathrm{NHC}=1,3-\mathrm{bis}(2,6-$ diisopropylphenyl)-4,5-imidazol-2-ylidene, 1,3-bis(mesityl)4,5-imidazol-2-ylidene, 1,3-bis(mesityl)-4,5-dihydroimidazol2-ylidene, 1,3-bis(2,6-diisopropylphenyl)-4,5-dihydroimidazol2 -ylidene). ${ }^{28}$

Since the transmetalation reaction of $\left[\mathrm{Cp}^{*} \mathrm{RuCl}(\mathrm{COD})\right]$ with the silver bis-carbene in 1,2-dichloroethane takes place with oxidation of the metal center to $\mathrm{Ru}^{\mathrm{III}}$ to yield $\mathbf{1}$, it was not possible to use this synthetic approach for the preparation of the $\mathrm{Ru}^{\mathrm{II}}$ target compound $[\mathrm{Cp} * \mathrm{RuCl}(\mathrm{L})]$. Alternatively, we used the direct reaction of $\left[\mathrm{Cp}^{*} \mathrm{RuCl}(\mathrm{COD})\right]$ with the biscarbene $\mathbf{L}$ generated in situ by deprotonation of the bis(imidazolium) salt $\left[\mathrm{LH}_{2}\right] \mathrm{Cl}_{2}$ using an excess of $\mathrm{LiBu}^{n}$ in tetrahydrofuran. In this fashion, the complex $[\mathrm{Cp} * \mathrm{RuCl}(\mathrm{L})]$ (2) (Chart 1) was isolated in the form of an extremely airsensitive yellow microcrystalline material.

Chart 1. Preparation of Complexes 1 and 2

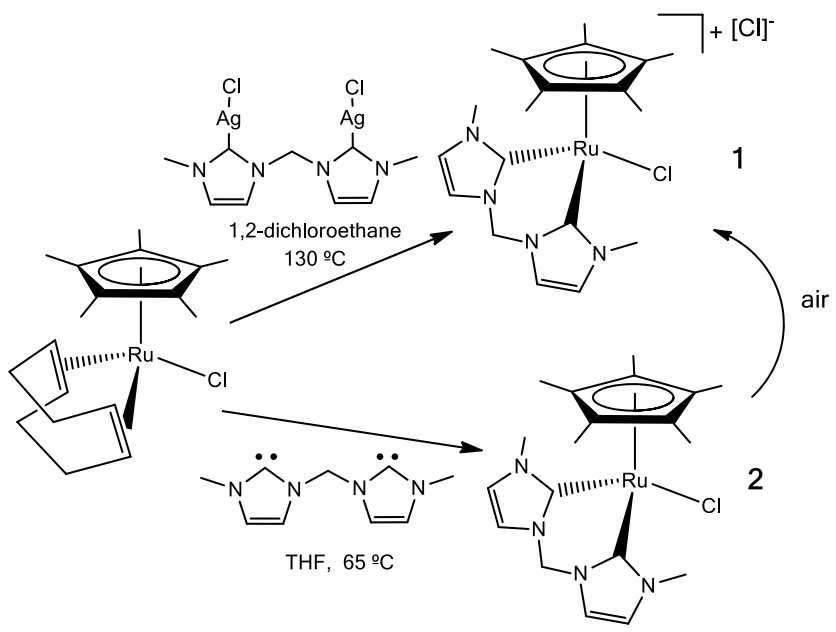

Compound $\mathbf{2}$ is extremely air-sensitive and turns cherry red immediately upon exposure to atmospheric oxygen. This color is consistent with the oxidation to the $\mathrm{Ru}^{\mathrm{III}}$ cation $\left[\mathrm{Cp}^{*} \mathrm{RuCl}-\right.$ $(\mathrm{L})]^{+}$. It is very sparingly soluble in $\mathrm{C}_{6} \mathrm{D}_{6}$, and it reacts with chlorinated solvents yielding oxidation products. Its ${ }^{1} \mathrm{H}$ NMR spectrum in THF- $d_{8}$ at room temperature consists of very broad features. The resonances become sharper when the temperature is raised. At $65{ }^{\circ} \mathrm{C}$, the spectrum is reasonably well-resolved, and shows one broad singlet for the $\mathrm{Cp}^{*}$ ring protons, one singlet for the protons of the methyl substituents of the imidazolylidene rings, and two characteristic $A B$ doublet 
signals with a coupling constant of $11.6 \mathrm{~Hz}$ corresponding to the methylene bridge protons, which become diastereotopic upon bidentate coordination of the ligand to the $\mathrm{Ru}$ atom. The protons of the double bond of the imidazolylidene rings appear as two broad singlets near $7 \mathrm{ppm}$. Similar NMR features have been observed on the complex $[\mathrm{TpRuCl}(\mathbf{L})] .{ }^{21}$ The ${ }^{13} \mathrm{C}\left\{{ }^{1} \mathrm{H}\right\}$ NMR signal of the equivalent carbene carbon atoms of $\mathbf{2}$ was not observed. It is assumed that it is too broad even at high temperature and it merges with the baseline. All the resonances for the other carbon atoms of the ligands $\mathbf{L}$ and $\mathrm{Cp}^{*}$ appear in the expected positions. located as expected for $\mathrm{Ru}-\mathrm{NHC}$ compounds. . $^{13,17,17,23,25,26}$ The temperature dependence of the NMR spectra is interpreted in terms of the rapid exchange of the chloride ligand with the THF- $d_{8}$ donor molecule (Chart 2).

Chart 2. Proposed Exchange in Solution of Chloride Ligand with THF- $d_{8}$
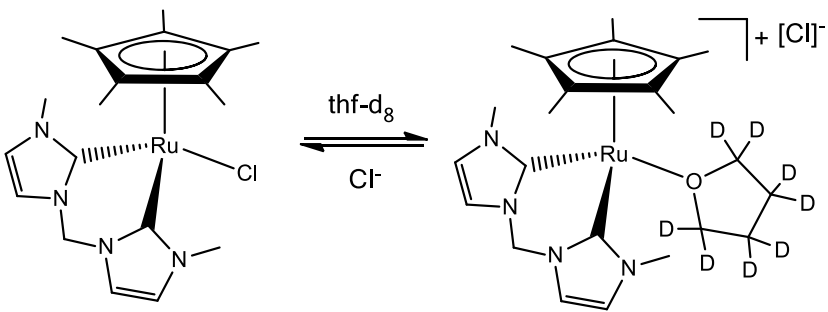

In fact, the chloride ligand in $\mathbf{2}$ is easily replaced by a range of donor molecules in the presence of a suitable chloride scavenger. Thus, 2 reacts with acetonitrile and $\mathrm{NaBPh}_{4}$ in $\mathrm{MeOH}$ at room temperature furnishing the complex $[\mathrm{Cp} * \mathrm{Ru}-$ $(\mathrm{MeCN})(\mathbf{L})]\left[\mathrm{BPh}_{4}\right](3)$. Recrystallization from acetonitrile/ methanol yielded amber crystals suitable for X-ray structure analysis. An ORTEP view of the complex cation $\left[\mathrm{Cp}^{*} \mathrm{Ru}-\right.$ $(\mathrm{MeCN})(\mathrm{L})]^{+}$in 3 is shown in Figure 2, together with the most relevant bond distances and angles.

The complex cation in 3 has a three-legged piano stool structure. The bis-carbene chelating bite angle $\mathrm{C}(11)-\mathrm{Ru}(1)-$ $\mathrm{C}(12)$ of $85.3(2)^{\circ}$ is within the expected range. ${ }^{21,25-27}$ The average dihedral angle between the plane defined by the atoms $\mathrm{C}(10)-\mathrm{Ru}(1)-\mathrm{C}(15)$ and the imidazol rings is $35.3^{\circ}$, still above the average values for the same angle in other complexes containing the same ligand $\mathbf{L}$, but very similar to the value found for compound 1 . The $\mathrm{Ru}-\mathrm{C}$ distances for the $\mathrm{NHC}$ ligand of 2.029(4) and 2.035(4) $\AA$ are both of the same order and consistent with $\mathrm{Ru}-\mathrm{C}$ separations expected for $\sigma$-bonds. The acetonitrile ligand is almost linearly assembled to ruthenium. The $\mathrm{Ru}(1)-\mathrm{N}(5)$ and $\mathrm{N}(5)-\mathrm{C}(20)$ bond lengths of 2.051(3) and 1.134(4) A respectively compare well with the values of 2.043(5) and 1.128(7) $\AA$ found in $[\mathrm{Cp} * \mathrm{Ru}(\mathrm{MeCN})$ $\left(\kappa^{2}-\mathrm{C}, N\right.$-picolyl- $\left.\left.{ }^{\mathrm{Me}} \mathrm{I}\right)\right]\left[\mathrm{BAr}^{\prime}{ }_{4}\right]$ (picolyl- ${ }^{\mathrm{Me}} \mathrm{I}=3$-methyl-1-(2picolyl)imidazol-2-ylidene). ${ }^{17}$ All other dimensions in the structure are in the expected ranges and are unexceptional. Complex 3 is far more stable toward atmospheric oxygen than 2. It can be handled as a solid in the air without visible decomposition or oxidation. It shows a medium intensity IR band at $2252 \mathrm{~cm}^{-1}$ corresponding to $\nu(\mathrm{C} \equiv \mathrm{N})$ in the acetonitrile ligand. Its ${ }^{1} \mathrm{H}$ NMR spectrum in acetonitrile- $d_{3}$ shows the two characteristic $A B$ doublet signals for the methylene bridge protons as expected. In this case, the ${ }^{13} \mathrm{C}\left\{{ }^{1} \mathrm{H}\right\}$ NMR signal of the equivalent carbene carbon atoms of 3 appear clearly on the spectrum at 193.0 ppm, i.e., in the

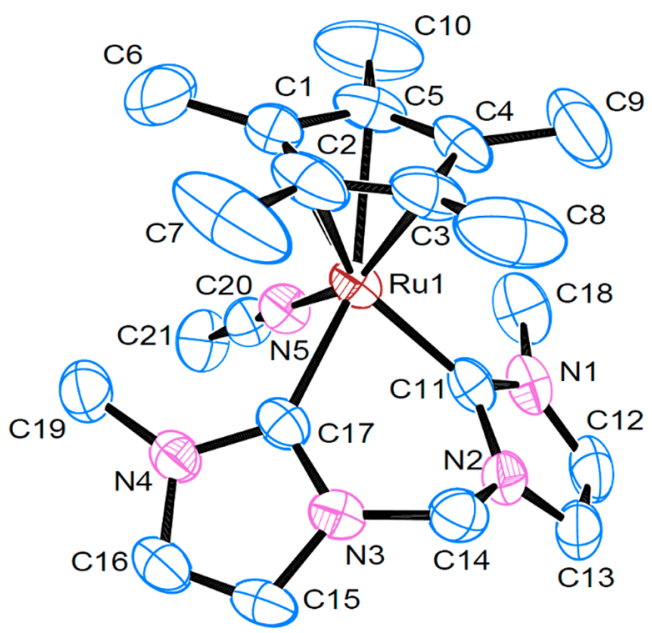

Figure 2. ORTEP drawing (30\% displacement ellipsoids, hydrogen atoms omitted) of $[\mathrm{Cp} * \mathrm{Ru}(\mathrm{MeCN})(\mathbf{L})]^{+}$in 3 . Selected bond lengths $(\AA)$ and angles (deg): $\mathrm{Ru}(1)-\mathrm{C}(11)$ 2.029(4), $\mathrm{Ru}(1)-\mathrm{C}(17)$ 2.035(4), $\mathrm{Ru}(1)-\mathrm{N}(5)$ 2.051(3), $\mathrm{Ru}(1)-\mathrm{C}(1) 2.224(5), \mathrm{Ru}(1)-$ $\mathrm{C}$ (2) 2.194(5), $\mathrm{Ru}(1)-\mathrm{C}(3)$ 2.166(4), $\mathrm{Ru}(1)-\mathrm{C}(4)$ 2.206(4), $\mathrm{Ru}(1)-\mathrm{C}(5) \quad 2.204(4), \mathrm{C}(20)-\mathrm{N}(5)$ 1.134(4), $\mathrm{C}(20)-\mathrm{C}(21)$ 1.464(5); $\mathrm{C}(11)-\mathrm{Ru}(1)-\mathrm{C}(17) \quad 83.3(1) ; \quad \mathrm{Ru}(1)-\mathrm{N}(5)-\mathrm{C}(20)$ $179.4(3), \quad \mathrm{N}(5)-\mathrm{C}(20)-\mathrm{C}(21) \quad 177.7(4), \mathrm{N}(2)-\mathrm{C}(14)-\mathrm{N}(3)$ $110.6(3)$.

expected range for $\mathrm{Ru}-\mathrm{NHC}$ compounds. Compound 3 is a convenient and efficient catalyst precursor for hydrogen transfer reactions to ketones, as discussed below.

Complex 2 reacts with $\mathrm{NaBPh}_{4}$ in methanol under $\mathrm{N}_{2}$ yielding a yellow microcrystalline precipitate which exhibits a strong band at $2050 \mathrm{~cm}^{-1}$ in its Raman spectrum, attributable to $\nu(\mathrm{N} \equiv \mathrm{N})$ in a bridging dinitrogen ligand attached to two $\mathrm{Ru}$ atoms. As expected, this band is inactive and does not show on the IR spectrum. This observation is consistent with the formation of the binuclear complex $\left[\{\mathrm{Cp} * \mathrm{Ru}(\mathrm{L})\}_{2}\left(\mu-\mathrm{N}_{2}\right)\right]$ $\left[\mathrm{BPh}_{4}\right]_{2}(4)$. The value for the Raman $\nu(\mathrm{N} \equiv \mathrm{N})$ band compare well with data in the literature for bridging dinitrogen complexes of ruthenium. ${ }^{23,29,30}$ The position of this band in $\mathbf{4}$ appears shifted ca. $50 \mathrm{~cm}^{-1}$ to lower wavenumbers with respect to the $\nu(\mathrm{N} \equiv \mathrm{N})$ in the homologous complex $\left[\{\mathrm{TpRu}(\mathrm{L})\}_{2}(\mu\right.$ $\left.\left.\mathrm{N}_{2}\right)\right]\left[\mathrm{BAr}_{4}^{\prime}\right]_{2}\left(2106 \mathrm{~cm}^{-1}\right){ }^{21}$ consistent with a slight increase of the relaxation of the coordinated $\mathrm{N} \equiv \mathrm{N}$ in 4 in comparison with the latter. At variance with $\left[\{\operatorname{TpRu}(\mathrm{L})\}_{2}\left(\mu-\mathrm{N}_{2}\right)\right]\left[\mathrm{BAr}_{4}{ }_{4}\right]_{2}$, which contains a dinitrogen ligand strongly bound to ruthenium, compound $\mathbf{4}$ is very labile and the compound is very reactive. Whereas the reaction of $\left[\{\mathrm{TpRu}(\mathbf{L})\}_{2}(\mu\right.$ $\left.\left.\mathrm{N}_{2}\right)\right]\left[\mathrm{BAr}_{4}^{\prime}\right]_{2}$ with $\mathrm{CO}$ or acetonitrile is very sluggish, 4 reacts readily with $\mathrm{MeCN}$ furnishing complex 3. It also reacts with chlorinated solvents such as dichloromethane and chloroform yielding dark red solutions with display complex NMR spectra. We found nitromethane as the best solvent to be used in this system due to its polarity and poor coordinating abilities. Thus, clean ${ }^{1} \mathrm{H}$ and ${ }^{13} \mathrm{C}\left\{{ }^{1} \mathrm{H}\right\}$ NMR spectra were obtained in nitromethane- $d_{3}$. One singlet for $\mathrm{Cp}^{*}$ and two $\mathrm{AB}$ doublet signals for the methylene bridge protons are the most characteristic features of the ${ }^{1} \mathrm{H}$ NMR spectrum. The equivalent carbene carbon atoms appear as one singlet at $185.1 \mathrm{ppm}$ on the ${ }^{13} \mathrm{C}\left\{{ }^{1} \mathrm{H}\right\}$ NMR spectrum. We attempted recrystallization of 4 in a mixture nitromethane/ethanol. Dark orange crystals were obtained. These crystals showed a strong band at $1813 \mathrm{~cm}^{-1}$ on the IR spectrum. This band was absent in the compound prior to recrystallization. X-ray structure 
analysis revealed that this product is the unexpected nitrosyl complex $[\mathrm{Cp} * \mathrm{Ru}(\mathrm{NO})(\mathrm{L})]\left[\mathrm{BPh}_{4}\right]_{2}(\mathbf{5})$. An ORTEP view of the complex cation $[\mathrm{Cp} * \mathrm{Ru}(\mathrm{NO})(\mathbf{L})]^{2+}$ in $\mathbf{5}$ is shown in Figure 3, together with the most relevant bond distances and angles.

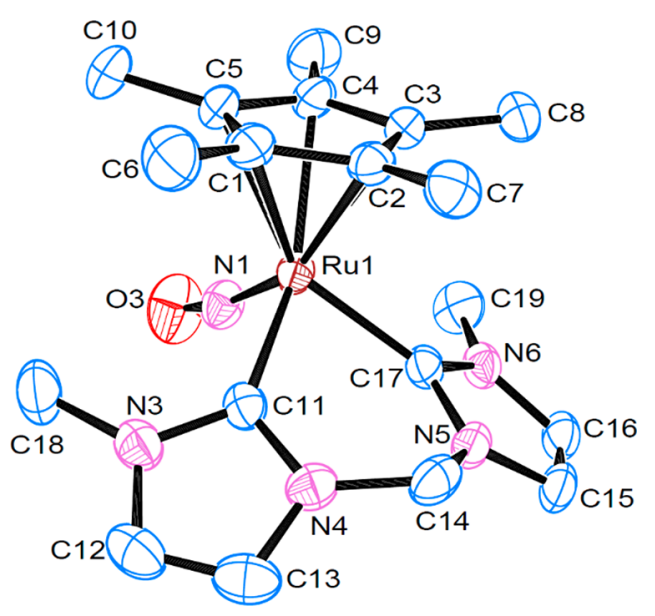

Figure 3. ORTEP drawing (30\% displacement ellipsoids, hydrogen atoms omitted) of one of the two identical molecules [Cp* $\mathrm{Ru}(\mathrm{NO})$ $(\mathrm{L})]^{2+}$ in 5. Selected bond lengths $(\AA)$ and angles (deg): $\mathrm{Ru}(1)-$ $\mathrm{C}(11) 2.056(4), \mathrm{Ru}(1)-\mathrm{C}(17) 2.057(3), \mathrm{Ru}(1)-\mathrm{N}(1)$ 1.769(3), $\mathrm{Ru}(1)-\mathrm{C}(1)$ 2.251(3), $\mathrm{Ru}(1)-\mathrm{C}(2)$ 2.205(4), $\mathrm{Ru}(1)-\mathrm{C}(3)$ 2.260(5), $\mathrm{Ru}(1)-\mathrm{C}(4)$ 2.271(4), $\mathrm{Ru}(1)-\mathrm{C}(5) \quad 2.270(3), \mathrm{N}(1)-$ $\mathrm{O}(3) 1.140(4) ; \mathrm{C}(11)-\mathrm{Ru}(1)-\mathrm{C}(17) 83.2(1), \mathrm{Ru}(1)-\mathrm{N}(1)-\mathrm{O}(3)$ 169.6(3).

The crystal structure of $\mathbf{5}$ consists of two virtually identical molecules $[\mathrm{Cp} * \mathrm{Ru}(\mathrm{NO})(\mathbf{L})]^{2+}$ and two $\left[\mathrm{BPh}_{4}\right]^{-}$anions per metal cation. The crystal also contains one nitromethane solvate molecule per ruthenium. The $[\mathrm{Cp} * \mathrm{Ru}(\mathrm{NO})(\mathbf{L})]^{2+}$ ion adopts a three-legged piano stool geometry, with almost identical $\mathrm{Ru}(1)-\mathrm{C}(11)$ and $\mathrm{Ru}(1)-\mathrm{C}(17)$ distances for the NHC ligand of 2.056(4) and 2.057(3) ̊. The average dihedral angle between the plane defined by the atoms $\mathrm{C}(11)-\mathrm{Ru}(1)-$ $C(17)$ and the imidazol rings is $29.6^{\circ}$, smaller than the values found for compounds 1 and 3, but within the range observed for other complexes containing the $\mathbf{L}$ ligand. The nitrosyl ligand is very slightly bent, with a $\mathrm{Ru}(1)-\mathrm{N}(1)-\mathrm{O}(3)$ angle of 169.6(3) Å. The $\mathrm{Ru}(1)-\mathrm{N}(1)$ and $\mathrm{N}(1)-\mathrm{O}(3)$ separations of 1.769 (3) and $1.140(4) \AA$ respectively compare well with the values found for the nitrosyl complex $\left[\mathrm{Ru}\left(\mathrm{L}^{1}\right)(\mathrm{NO}) \mathrm{Cl}_{2}\right]\left(\mathrm{L}^{1}=\right.$ $\left(N^{\prime}\right.$-phenyl- $N^{\prime}$-(pyridin-2-yl)picolinohydrazide $\left.)\right),{ }^{31}$ and in the $\mathrm{Ru}^{\mathrm{II}}$ nitrosyl complexes with pyridine-functionalized $\mathrm{N}$ heterocyclic carbene ligands $\left[\mathrm{Ru}\left(\mathrm{L}^{2}\right)(\mathrm{NO}) \mathrm{Cl}_{3}\right]\left(\mathrm{L}^{2}=3\right.$-tertbutyl-1-(2-pyridyl)imidazol-2-ylidene, 3- $n$-butyl-1-(2-pyridyl)imidazol-2-ylidene, 3-tert-butyl-1-picolylimidazol-2-ylidene). ${ }^{32}$ The formation of the nitrosyl complex 5 at the expense of the dinitrogen derivative $\mathbf{4}$ is completely unexpected. The crystals of 5 were isolated in low yield based on ruthenium, and the origin of the nitrosyl ligand is unclear. We can only speculate that it comes from nitromethane, but we are unsure about the chemical reactions leading to the ultimate products, as there are no precedents for this. One reviewer tentatively suggested the possibility of formation of the nitrosyl complex 5 by the transfer hydrogenation between nitromethane and EtOH during recrystallization. In fact, we assume that other metalcontaining products must be formed in the process, but we failed to identify any other species. We monitored by NMR a solution of 4 in nitromethane- $d_{3}$ under dinitrogen over several days. We were able to detect gradually increasing signals for the nitrosyl compound 5, mixed with many other resonances and broad features corresponding to unidentified species. We did not detect the formation of any hydride containing species in the overall process, which is not clean nor simple, and the nitrosyl species $\mathbf{5}$ was the only fully characterized compound in this most intriguing reaction sequence.

Compound $\mathbf{4}$ also acts as a catalyst precursor for ketone hydrogen transfer reactions (vide infra). The dinitrogen ligand in 4 is readily replaced by a number of donor molecules furnishing the corresponding complexes. These reactions are summarized in Scheme 1.

Scheme 1. Reactivity of the Bridging Dinitrogen Complexes 4

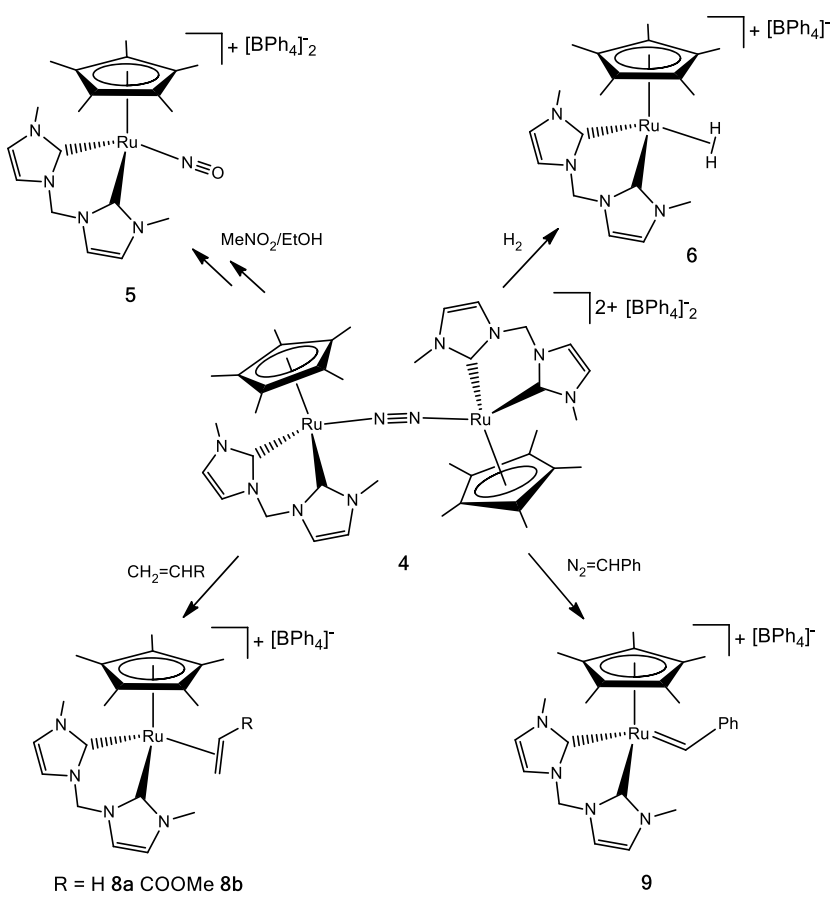

Thus, 4 reacts with $\mathrm{H}_{2}$ in nitromethane affording the labile dihydrogen complex $\left[\mathrm{Cp} * \mathrm{Ru}\left(\mathrm{H}_{2}\right)(\mathbf{L})\right]\left[\mathrm{BPh}_{4}\right](\mathbf{6})$. This compound was isolated by reaction of 2 with $\mathrm{NaBPh}_{4}$ in methanol under a dihydrogen atmosphere in the form of an off white solid. All subsequent manipulations were performed under an atmosphere of argon unless otherwise stated. The ${ }^{1} \mathrm{H}$ NMR spectrum of 6 in nitromethane- $d_{3}$ under dihydrogen shows a broad resonance at $-7.81 \mathrm{ppm}$ attributable to the protons of the coordinated dihydrogen. As it is characteristic of dihydrogen ligands, ${ }^{33}$ this resonance exhibits a short longitudinal relaxation time $T_{1}$ of $21.4 \mathrm{~ms}$ at $248 \mathrm{~K}$ (500 $\mathrm{MHz}$ ). This was the shortest measured $T_{1}$, as the minimum value could not be determined due to freezing of the solvent. In any case, the value is fully consistent with the presence of a coordinated dihydrogen molecule. In general, dihydrogen complexes stabilized with NHC-ligands are not very common. $^{34} \mathrm{We}$ were not able to prepare the homologous complex $\left[\mathrm{TpRu}\left(\mathrm{H}_{2}\right)(\mathbf{L})\right]^{+},{ }^{21}$ an observation that emphasizes the difference between the $\{\mathrm{Cp} * \mathrm{Ru}(\mathrm{L})\}$ and $\{\mathrm{TpRu}(\mathrm{L})\}$ moieties. The dihydrogen complex $\mathbf{6}$ has also been successfully used as catalyst precursor for ketone hydrogen transfer 
reactions. The dihydrogen ligand in $\mathbf{6}$ is readily deprotonated by strong bases yielding the corresponding neutral monohydride complex. Thus, the reaction of $\mathbf{6}$ with $\mathrm{KOBu}^{t}$ in tetrahydrofuran under dihydrogen afforded $[\mathrm{Cp} * \mathrm{RuH}(\mathrm{L})](7)$ in high yield as a yellow microcrystalline, air-sensitive solid (Chart 3).

\section{Chart 3. Deprotonation of the Dihydrogen Complex 6}
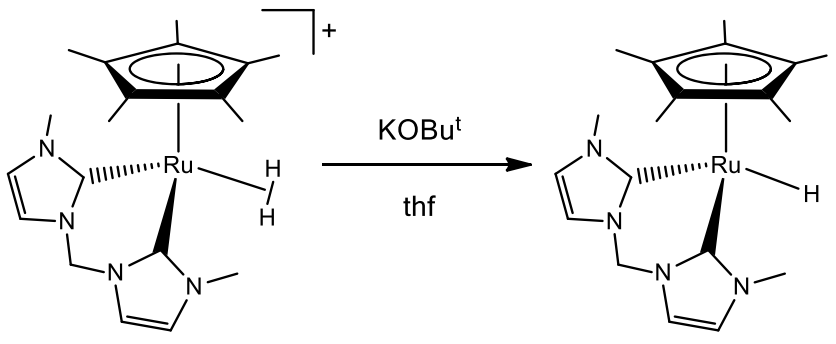

7

A medium band at $1780 \mathrm{~cm}^{-1}$ in the IR spectrum is attributable to $\nu(\mathrm{RuH})$, whereas one singlet at $-11.65 \mathrm{ppm}$ in the ${ }^{1} \mathrm{H}$ NMR spectrum corresponds to the hydride proton. Since 7 it is formed in strongly basic conditions, it is assumed that this compound must be involved in the catalytic ketone hydrogen transfer reactions described below, and it possibly represents a key intermediate in the overall catalytic cycle.

Compound 4 also reacts with olefins $\mathrm{CH}_{2}=\mathrm{CHR}(\mathrm{R}=\mathrm{H}$, $\mathrm{COOMe})$ to yield the corresponding $\eta^{2}$-adducts $\left[\mathrm{Cp} * \mathrm{Ru}\left(\eta^{2}\right.\right.$ $\left.\left.\mathrm{CH}_{2}=\mathrm{CHR}\right)(\mathrm{L})\right]\left[\mathrm{BPh}_{4}\right](\mathrm{R}=\mathrm{H} \mathbf{8 a}$, COOMe 8b) (Scheme $1)$. These compounds were not isolated. They were generated in solution either by bubbling ethylene or adding an excess of methyl acrylate to a nitromethane- $d_{3}$ solution of $\mathbf{4}$ under argon, and were characterized in solution by NMR spectroscopy. The resonances for the proton and carbon atoms of coordinated ethylene in $\mathbf{8 a}$ appear at 2.14 and $47.2 \mathrm{ppm}$ on the respective ${ }^{1} \mathrm{H}$ and ${ }^{13} \mathrm{C}\left\{{ }^{1} \mathrm{H}\right\}$ NMR spectra. In the case of $\mathbf{8 b}$, only one diastereoisomer is observed as indicated by one single $\mathrm{Cp}^{*}$ signal in the ${ }^{1} \mathrm{H}$ NMR spectrum, but the presence of the COOMe substituent on the $\eta^{2}$-alkene ligand renders the imidazolylidene rings inequivalent. Thus, two resonances are observed for the methyl substituents at the nitrogen, and four separate resonances for the $\mathrm{H}$ and $\mathrm{C}$ atoms in the positions 3 and 4 of the NHC rings. Most notably, two carbene carbon atom signals at 180.8 and $183.9 \mathrm{ppm}$ are present on the ${ }^{13} \mathrm{C}\left\{{ }^{1} \mathrm{H}\right\}$ NMR spectrum. The two $\mathrm{AB}$ doublet signals for the methylene bridge protons are maintained.

Compound $\mathbf{4}$ reacts with freshly prepared solutions of phenyldiazomethane in tetrahydrofuran under argon yielding the carbene complex $[\mathrm{Cp} * \mathrm{Ru}=\mathrm{CHPh}(\mathrm{L})]\left[\mathrm{BPh}_{4}\right]$ (9) (Scheme 1). This compound can be also prepared starting from the dihydrogen derivative 6 in a similar fashion. We have used a similar synthetic approach in the past for the preparation of the carbene complexes $\left[\mathrm{Cp} * \mathrm{Ru}=\mathrm{CHPh}\left(\kappa^{2}\right.\right.$ $\left.\left.P, N-{ }^{i} \mathrm{Pr}_{2} \mathrm{PNHPy}\right)\right]\left[\mathrm{BAr}_{4}{ }_{4}\right]^{35}\left(\mathrm{Py}=\mathrm{C}_{5} \mathrm{H}_{4} \mathrm{~N}\right)$ and $[\mathrm{TpRu}=$ $\left.\mathrm{CHPh}(\mathrm{Cl})\left(\mathrm{PMe}^{i} \mathrm{Pr}_{2}\right)\right] .{ }^{36}$ The ${ }^{1} \mathrm{H}$ NMR spectrum of compound 9 is characterized by the presence of the carbene proton resonance at $15.7 \mathrm{ppm}$. This resonance is correlated with a signal at $287.2 \mathrm{ppm}$ in the ${ }^{13} \mathrm{C}\left\{{ }^{1} \mathrm{H}\right\}$ spectrum as shown by a gHSQC 2D NMR experiment. The carbene carbon atoms of the $\mathbf{L}$ ligand appear at $184.0 \mathrm{ppm}$, i.e., in the expected range. Compound 9 is remarkably stable, and unreactive toward ethylene in nitromethane solution. Alkylidene complexes can be protonated by strong acids, and thus we prepared the dicationic $\eta^{2}$-benzyl derivative $\left[\mathrm{Cp} * \mathrm{Ru}\left(\kappa^{2}-P, N-\mathrm{P}^{i} \mathrm{Pr}_{2} \mathrm{NHPy}\right)\right.$ $\left.\left(\eta^{2}-\mathrm{CH}_{2} \mathrm{C}_{6} \mathrm{H}_{5}\right)\right]\left[\mathrm{CF}_{3} \mathrm{SO}_{3}\right]_{2}$ by reaction of $\left[\mathrm{Cp} * \mathrm{Ru}=\mathrm{CHPh}\left(\kappa^{2}-\right.\right.$ $\left.\left.P, N-{ }^{i} \mathrm{Pr}_{2} \mathrm{PNHPy}\right)\right]\left[\mathrm{BAr}^{\prime}{ }_{4}\right]$ with an excess of trifluoromethanesulfonic acid in dichloromethane. ${ }^{35}$ Addition of an excess of $\mathrm{HBF}_{4} \cdot \mathrm{OEt}_{2}$ to 9 in nitromethane at room temperature led to an immediate color change of the solution from dark red to green. However, the ${ }^{1} \mathrm{H}$ NMR did not show resonances for any recognizable species. It seems that the products undergo decomposition under these reaction conditions, and the system was not further investigated.

We have been studying in depth the reactivity of allenylidene ligands bound to a ruthenium center supported by $\mathrm{N}$ heterocyclic carbene ligands in the general context of the activation of propargyl alcohols by the $\mathrm{Ru}-\mathrm{NHC}$ fragment. ${ }^{21}$ Thus, the reactivity toward the addition of nucleophiles to the allenylidene ligand attached to the fragment $\left\{[\operatorname{TpRu}(\mathbf{L})]^{+}\right\}$has been studied in detail, and it was compared to that of related systems containing tertiary phosphines as ancillary ligands. We found that nucleophilic additions to the allenylidene ligand may take place alternatively at the $\mathrm{C}_{\alpha}$ or $\mathrm{C}_{\beta}$ atoms depending on the $\mathrm{R}$ substituents present on the propargyl alcohol, and on the nature of the incoming nucleophiles. We wanted to see the effect of replacing $\mathrm{Tp}$ by the stronger donor $\mathrm{Cp} *$ ligand on the reactivity of the allenylidene complex. Hence, we prepared the allenylidene derivative $\left[\mathrm{Cp} * \mathrm{Ru}=\mathrm{C}=\mathrm{C}=\mathrm{CPh}_{2}(\mathrm{~L})\right]\left[\mathrm{BPh}_{4}\right]$ (10) by reaction of 2 with $\mathrm{HC} \equiv \mathrm{CC}(\mathrm{OH}) \mathrm{Ph}_{2}$ and $\mathrm{NaBPh}_{4}$ in $\mathrm{MeOH}$ at $60{ }^{\circ} \mathrm{C}$ (Chart 4).

\section{Chart 4. Preparation of the Allenylidene Complex 10}

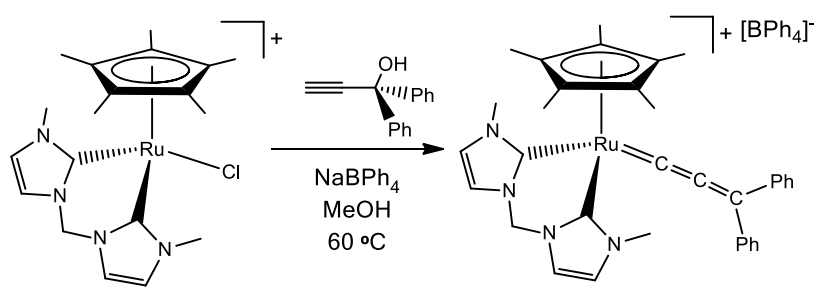

10

The allenylidene complex 10 shows a strong $\nu(\mathrm{C}=\mathrm{C}=\mathrm{C})$ band in the IR spectrum at $1880 \mathrm{~cm}^{-1}$. The signals observed at $\delta$ 274.9, 225.6, and $139.8 \mathrm{ppm}$ in the ${ }^{13} \mathrm{C}\left\{{ }^{1} \mathrm{H}\right\}$ NMR spectrum are respectively characteristic for the $\mathrm{C}_{\alpha}, \mathrm{C}_{\beta}$, and $\mathrm{C}_{\gamma}$ atoms of the allenylidene ligand, whereas the resonance for the carbene carbon atoms of the $\mathbf{L}$ ligand appear at $178.0 \mathrm{ppm}$. The signal for the $\mathrm{C}_{\alpha}$ atom in $\mathbf{1 0}$ is shifted upfield ca. $30 \mathrm{ppm}$ compared to the value observed for the homologous complex $[\mathrm{TpRu}=$ $\left.\left.\mathrm{C}=\mathrm{C}=\mathrm{CPh}_{2}(\mathrm{~L})\right]\left[\mathrm{BPh}_{4}\right](305.0 \mathrm{ppm})\right)^{21}$ Likewise, the IR $\nu(\mathrm{C}=\mathrm{C}=\mathrm{C})$ band for the allenylidene ligand in $\mathbf{1 0}$ appears also shifted to lower wavenumbers compared to its $\mathrm{TpRu}$ counterpart $\left(1913 \mathrm{~cm}^{-1}\right)$. The latter exhibits a rich reactivity toward a variety of $\mathrm{N}$ - and S-donor nucleophiles such as pyrazole, piperidine, 2-pyridinethiol or 1,3-benzenedithiol leading to vinylcarbene complexes resulting from the addition to the $\mathrm{C}_{\alpha}$ atom of the allenylidene ligand. ${ }^{21}$ At variance with this, complex 10 is apparently much less reactive toward nucleophiles, and did not show any visible reaction with pyrazole at $55^{\circ} \mathrm{C}$ in acetone- $d_{6}$ after $18 \mathrm{~h}$.

Ketone Transfer Hydrogenation. The transfer hydrogenation of ketones was explored using acetophenone (11) as 
model substrate, with 2-propanol as the hydrogen source in the presence of $0.5 \mathrm{~mol} \%$ of ruthenium complexes 3, 4, and 6 at $80{ }^{\circ} \mathrm{C}$. A catalytic amount of $\mathrm{KO}^{i} \mathrm{Pr}$ was initially used as base. The results given in Table 1 showed that catalysts 3 and 4 led

Table 1. Optimization of Reaction Conditions for Transfer Hydrogenation of Acetophenone (11) with Ruthenium Complexes $^{a}$<smiles>CC(=O)c1ccccc1</smiles>

11

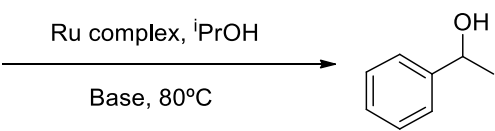

$( \pm)-11 \mathrm{a}$

$\begin{array}{lccccc}\text { entry } & \text { catalyst (mol \%) } & \text { base }(\mathrm{mol} \%) & t(\mathrm{~h}) & \text { yield }(\%)^{b} & \mathrm{TOF}^{-1} \mathrm{~h}^{c} \\ 1 & 3(0.5) & \mathrm{KO}^{i} \operatorname{Pr}(10) & 2 & 13 & 13 \\ 2 & 3(0.5) & \mathrm{KO}^{i} \operatorname{Pr}(10) & 16 & 75 & 9.4 \\ 3 & \mathbf{4}(0.5) & \mathrm{KO}^{i} \operatorname{Pr}(10) & 2 & 19 & 19 \\ 4 & 4(0.5) & \mathrm{KO} \operatorname{Pr}(10) & 16 & 79 & 10 \\ 5 & 6(0.5) & \mathrm{KO} \operatorname{Pr}(10) & 2 & 75 & 75 \\ 6 & 6(0.5) & \mathrm{KOH}(10) & 2 & 94 & 94 \\ 7 & 6(0.5) & \mathrm{KOH}(5) & 2 & 94 & 94 \\ 8 & 6(0.5) & \mathrm{KOH}(5) & 1 & 81 & 162 \\ 9 & 6(0.5) & - & 16 & 0 & - \\ 10^{d} & 6(0.1) & \mathrm{KOH}(5) & 2 & 91 & 455 \\ 11 & - & \mathrm{KOH}(10) & 16 & 10 & -\end{array}$

${ }^{a}$ Unless noted otherwise, reactions were carried out with $2 \mathrm{mmol}$ of acetophenone in $2 \mathrm{~mL}$ of 2 -propanol at $80^{\circ} \mathrm{C}$. ${ }^{b}$ Determined by GCMS. ${ }^{c}$ Turnover frequency (moles of ketone converted to alcohol per mole of catalyst per hour). ${ }^{d} 4 \mathrm{mmol}$ of acetophenone in $4 \mathrm{~mL}$ of 2 propanol.

to the desired product $( \pm)-11$ a in low yields and TOF values after $2 \mathrm{~h}$ (Table 1, entries 1 and 3). With longer reaction times $(16 \mathrm{~h})$, yields increased to $75 \%$ and $79 \%$, respectively (Table 1 , entries 2 and 4). In contrast, complex 6 was found to be the best catalyst toward transfer hydrogenation under the same reaction conditions affording compound $( \pm)-11$ a in $75 \%$ yield after $2 \mathrm{~h}$ (Table 1 , entry 5). When $\mathrm{KOH}$ was used as base instead of $\mathrm{KO}^{i} \mathrm{Pr}$, the yield increased up to $94 \%$ in the presence of complex 6 (Table 1, entry 6). Reduction of the amount of $\mathrm{KOH}$ to $5 \mathrm{~mol} \%$ gave an identical result (Table 1, entry 7 ). These new conditions led to a higher catalytic activity after $1 \mathrm{~h}$ affording ( \pm )-11a in $81 \%$ yield with TOF value of $162 \mathrm{~h}^{-1}$ (Table 1, entry 8). However, the reaction did not take place in the absence of base (Table 1, entry 9). Interestingly, when the catalyst loading of complex 6 was reduced to $0.1 \mathrm{~mol} \%$, compound $( \pm)$-11a was formed in a similar yield with a TOF value of $455 \mathrm{~h}^{-1}$ after $2 \mathrm{~h}$ (Table 1, entry 10). Finally, we confirmed that compound $( \pm)-11$ a was only obtained in $10 \%$ yield in the absence of catalyst (Table 1, entry 11).

With the optimized conditions in hand, the scope of the transfer hydrogenation of ketones and aldehydes was investigated. A variety of ketones were suitable for this procedure giving the desired alcohols in high to good yields. The bulkier 2-acetonaphthone (12) underwent transfer hydrogenation to give alcohol $( \pm$ )-12a in $88 \%$ yield (Table 2, entry 1). Para-substituted phenylketones or benzophenones 13-15 bearing electron-withdrawing groups such as trifluoromethyl or chloro groups were well tolerated to afford the corresponding alcohols ( \pm )-13a-15a in $71-99 \%$ yields (Table 2, entries 2-4), whereas electron-donating substituents on aryl group such as $p$-methoxy group led to alcohol $( \pm)$-16a
Table 2. Screening of Substrates for Transfer Hydrogenation of Carbonyl Groups Catalyzed by Complex $6^{a}$

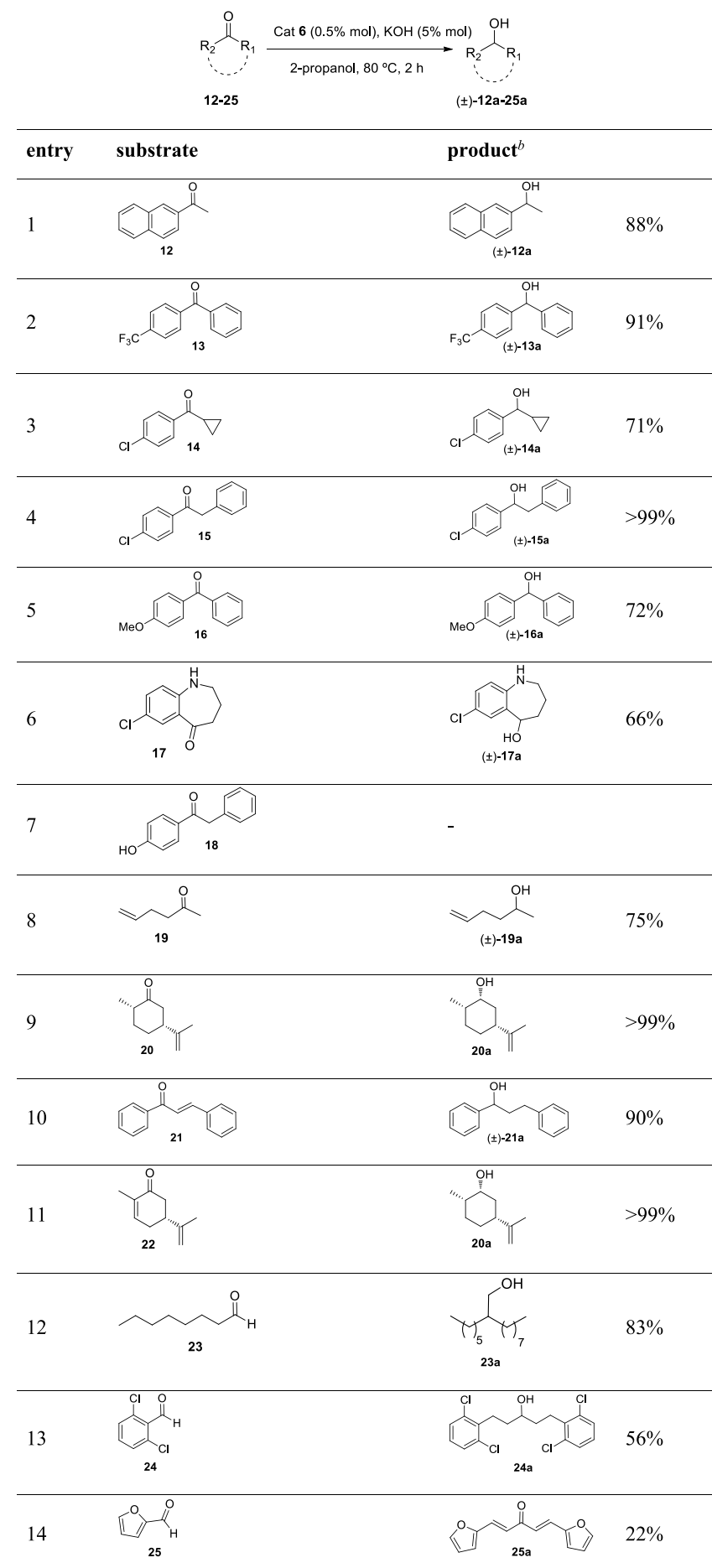

${ }^{a}$ Unless otherwise noted, reactions were carried out with $2 \mathrm{mmol}$ of substrate in $2 \mathrm{~mL}$ of 2 -propanol at $80{ }^{\circ} \mathrm{C}$ for $2 \mathrm{~h}$. ${ }^{b}$ Determined by GC-MS.

in $72 \%$ yield (Table 2, entry 5). Similarly, the transfer hydrogenation was compatible with benzoazepin-5-one (17) bearing 7-chloro substituent, providing the corresponding alcohol ( \pm )-17a in $66 \%$ yield (Table 2 , entry 6 ). However, the reaction was not compatible with the presence of a free 
hydroxyl group on the aromatic ring (Table 2, entry 7). Aliphatic ketones were also well tolerated. Hex-4-en-2-one (19) was transformed into alcohol $( \pm)-19$ a in $75 \%$ yield whereas (+)-dihydrocarvone (20) afforded stereoselectively compound 20a in quantitative yield (Table 2, entries 8-9). The absolute configuration of $20 \mathrm{a}$ was determined by NOE effects.

On the other hand, the transfer hydrogenation of $\alpha, \beta$ unsaturated ketones 21-22 was performed to produce the corresponding alkanols $( \pm)-21 \mathrm{a}$ and 20a with both $\mathrm{C}=\mathrm{C}$ and $\mathrm{C}=\mathrm{O}$ reduced in $90 \%$ and $99 \%$, respectively (Table 2 , entries 10-11).

We further extended our study to aldehydes 23-25. Unfortunately, the reaction failed to give the corresponding reduction products. The Guerbet-type alcohol 23a was obtained in $83 \%$ yield from octanal (23) (Table 2, entry 12) (Chart 5, a). The Guerbet reaction involves homocoupling of

\section{Chart 5. Formation of Products Derived from Guerbet-} Type Reactions

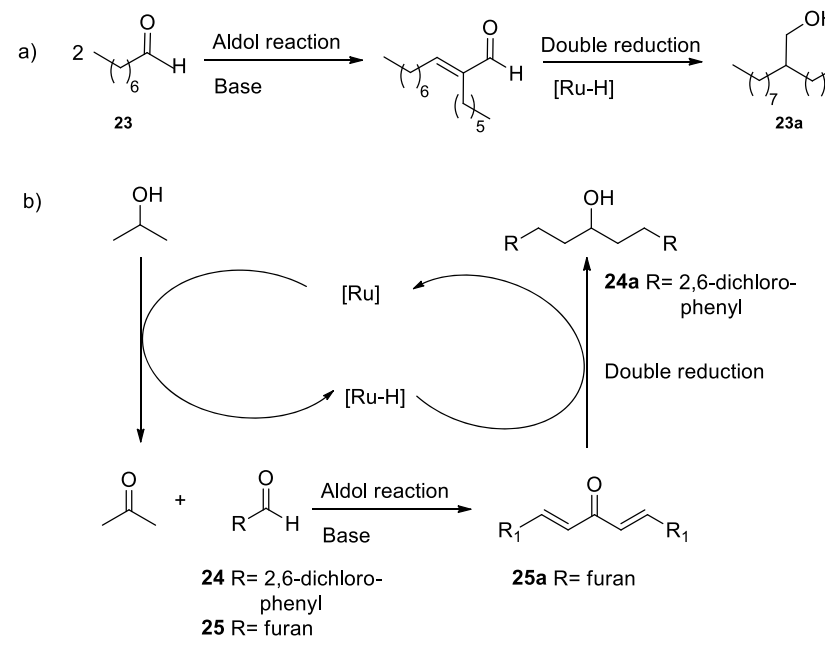

primary alcohols to obtain $\beta$-alkylated dimer alcohols where the new $\mathrm{C}-\mathrm{C}$ bond is generated by an aldol condensation. ${ }^{37}$ Recently, Ir, Rh, and $\mathrm{Ru}$ complexes have been reported to catalyze the Guerbet reaction and produce higher-order alcohols in a more economical and environmentally friendly manner. ${ }^{38}$ In most cases, these catalytic systems required temperature higher than $100{ }^{\circ} \mathrm{C}$. Compound 23a was also prepared starting from octanol in $80 \%$ yield in a similar fashion. Moreover, benzaldehyde derivative 24 performed a cross-coupling with 2-propanol to afford the saturated dimer 24a in $56 \%$ yield, whereas 2 -furfural (25) gave the unsaturated dimer 25a as major product (Table 2, entries 13-14). These findings indicate that complex $\mathbf{6}$ could be an efficient catalyst precursor for $\beta$-alkylation of secondary alcohols and $\alpha$ alkylation of ketones by borrowing hydrogen reaction (Chart $5, \mathrm{~b}) .^{39}$

In comparison with previously reported ruthenium(II) complexes bearing chelating NHCs, our catalytic system based on methylene-linked bis(NHC) ligands exhibits similar efficiency in a wide scope of substrates even with lower catalyst loadings allowing significant shortening of reaction times. ${ }^{17,18}$ In this sense, compound $\mathbf{6}$ seems to perform in ketone hydrogen transfer somewhat less efficiently than the picolylcarbene complex $\left[\mathrm{Cp} * \mathrm{Ru}(\mathrm{MeCN})\left(\kappa^{2}-\mathrm{C}, N-\right.\right.$ picolyl- $\left.\left.{ }^{\mathrm{Me}} \mathrm{I}\right)\right]\left[\mathrm{PF}_{6}\right]$ (picolyl- ${ }^{\mathrm{Me}} \mathrm{I}=3$-methyl-1-(2-picolyl)imidazol-2-ylidene) previously reported by our research group. ${ }^{17}$ This compound had already shown an excellent catalytic activity and wider scope compared to other previously reported ruthenium $^{40}$ or even iridium ${ }^{41}$ pyridyl-NHC complexes. The hydride transfer is a key step in many catalytic transformations, and further studies are in progress aimed to extend the use of these new complexes as catalysts for reactions of $\mathrm{N}$-alkylation of amines with alcohols.

\section{CONCLUSION}

We have hereby reported the synthesis and characterization of a series of novel pentamethylcyclopentadienylruthenium(II) complexes bearing the methylene linked bis(NHC) ligand bis(3-methylimidazol-2-ylidene)methane. The binuclear dinitrogen-bridged compound 4 displays a rich reactivity toward a range of small molecules. Compound 4 undergoes an unprecedented degradation in nitromethane solution leading to the nitrosyl derivative $\mathbf{5}$, which has been structurally characterized. Compounds 3, 4, and 6 act as catalyst precursors for the transfer hydrogenation of acetophenone. In particular, the dihydrogen complex 6 has proven to be a very efficient catalyst precursor, reaching a TOF of up to $455 \mathrm{~h}^{-1}$ at catalyst loadings of $0.1 \% \mathrm{~mol}$. Moreover, 6 exhibits high tolerance of functional groups on the reduction of a broad scope of aryl and aliphatic ketones giving rise the corresponding alcohols in high yields. Additionally, the transfer hydrogenation of aldehydes using 6 as a catalyst afforded Guerbet-type reaction products and the $\beta$-alkylation of 2 -propanol under mild conditions. The study of further organic transformations mediated by these novel complexes is currently in progress in our laboratory, and will be reported in due course.

\section{EXPERIMENTAL SECTION}

All synthetic operations were performed under a dry dinitrogen or argon atmosphere following conventional Schlenk techniques. Tetrahydrofuran, diethyl ether, and petroleum ether (boiling point range $40-60{ }^{\circ} \mathrm{C}$ ) were obtained oxygen- and water-free from a solvent purification apparatus. All other solvents (acetonitrile, dichloromethane, toluene, nitromethane, methanol, 2-propanol) were of anhydrous quality and used as received. All solvents were deoxygenated immediately before use. $[\mathrm{Cp} * \mathrm{RuCl}(\mathrm{COD})]$ was prepared according to the literature. ${ }^{42}$ The imidazolium salt bis(3methylimidazolium)methane dichloride $\left(\left[\mathrm{LH}_{2}\right] \mathrm{Cl}_{2}\right)$ was prepared following suitable adaptations of published procedures. ${ }^{25}$ IR spectra were taken in Nujol mulls on a FTIR spectrophotometer. Raman spectrum was recorded at the Instituto de Ciencia de Materiales-CSIC on a dispersive Raman microscope equipped with a $\mathrm{He}-\mathrm{Ne}$ laser $(\lambda=$ $532.14 \mathrm{~nm}$ ) using a working power of $0.2 \mathrm{~mW}$ in order to avoid overheating and alteration of the sample. Optical rotations were determined with a digital polarimeter. NMR spectra were taken on spectrometers operating at 400 or $500 \mathrm{MHz}\left({ }^{1} \mathrm{H}\right.$ frequency). Chemical shifts are given in ppm from $\mathrm{SiMe}_{4}\left({ }^{1} \mathrm{H}\right.$ and $\left.{ }^{13} \mathrm{C}\left\{{ }^{1} \mathrm{H}\right\}\right)$. ${ }^{1} \mathrm{H}$ and ${ }^{13} \mathrm{C}\left\{{ }^{1} \mathrm{H}\right\}$ NMR spectroscopic signal assignments were confirmed by ${ }^{1} \mathrm{H}$-gCOSY, gHSQCAD $\left({ }^{1} \mathrm{H}-{ }^{13} \mathrm{C}\right)$, and gHMBCAD $\left({ }^{1} \mathrm{H}-{ }^{13} \mathrm{C}\right)$ experiments. As a general feature, in the spectra of cationic compounds the signals for the $\left[\mathrm{BPh}_{4}\right]^{-}$anion are omitted. High resolution mass spectroscopy (HRMS) was performed in a Q-TOF mass spectrometer in the positive ion ESI mode. Silica gel (Merck) was used for column chromatography. TLC was performed on Merck Kiesegel 60 F254, 0.25 mm thick. GC-MS analyses were recorded in a Bruker Scion GC-TQ gas chromatograph coupled to a Bruker TQ mass spectrometer. Microanalyses were performed at the Servicio Central de Ciencia y Tecnologia, Universidad de Cádiz.

$[\mathrm{Cp} * \mathrm{RuCl}(\mathrm{L})] \mathrm{Cl}$ 1. A Fisher-Porter vessel was charged with a mixture of bis(3-methylimidazolium)methane dichloride $(0.25 \mathrm{~g}, 1$ 
$\mathrm{mmol}$ ) and $\mathrm{Ag}_{2} \mathrm{O}(0.28 \mathrm{~g}, 1.2 \mathrm{mmol})$. It was protected from the light by wrapping with aluminum foil. Then, 1,2-dichloroethane $(15 \mathrm{~mL})$ was added, and the mixture stirred at room temperature for $18 \mathrm{~h}$. After this time, a solution of $[\mathrm{Cp} * \mathrm{RuCl}(\mathrm{COD})](0.38 \mathrm{~g}, 1 \mathrm{mmol})$ in 1,2-dichloroethane $(15 \mathrm{~mL})$ was added. The resulting mixture was stirred for further $18 \mathrm{~h}$ at $130{ }^{\circ} \mathrm{C}$. A purple suspension was obtained. It was filtered through Celite, and the Celite washed with two portions of dichloromethane. The solvent of the filtered solution was removed in vacuo. The resulting purple microcrystalline product was washed with petroleum ether and dried in vacuo. Recrystallization from dichloromethane/petroleum ether afforded crystals suitable for $\mathrm{X}$-ray structure analysis. Yield (based upon $\mathrm{Ru}$ ): $0.21 \mathrm{~g}, 43 \%$. Calcd for $\mathrm{C}_{19} \mathrm{H}_{27} \mathrm{~N}_{4} \mathrm{Cl}_{2} \mathrm{Ru}$ : C, 47.21; H, 5.63; N, 11.59. Found: C, 47.29; $\mathrm{H}$, $5.71, \mathrm{~N}, 11.30$. The product is paramagnetic.

$[\mathrm{Cp} * \mathrm{RuCl}(\mathrm{L})]$ 2. A Schlenk tube was charged with bis(3methylimidazolium)methane dichloride (1.5 g, $6 \mathrm{mmol})$, deoxygenated and placed under dinitrogen. Deoxygenated tetrahydrofuran $(30 \mathrm{~mL})$ was added. It was cooled to $-80{ }^{\circ} \mathrm{C}$ and $\mathrm{LiBu}^{n}(7.5 \mathrm{~mL}$ of a 1.6 $\mathrm{M}$ solution, $12 \mathrm{mmol}$ ) was added via syringe. The mixture was warmed to room temperature and stirred for $2 \mathrm{~h}$. At the end of this time, a solution of $[\mathrm{Cp} * \mathrm{RuCl}(\mathrm{COD})](1.77 \mathrm{~g}, 4.66 \mathrm{mmol})$ in tetrahydrofuran $(25 \mathrm{~mL})$ was added. The resulting mixture was stirred overnight at $65{ }^{\circ} \mathrm{C}$. A brown-orange solution with a finely divided white precipitate was obtained. The suspension was filtered through Celite. The solvent was removed in vacuo, and the resulting yellowbrown, very air-sensitive microcrystalline product was washed with two portions of petroleum ether and dried in vacuo. Yield: $1.77 \mathrm{~g}$, $85 \%$. Calcd for $\mathrm{C}_{19} \mathrm{H}_{27} \mathrm{~N}_{4} \mathrm{ClRu}$ : C, 50.94; H, 6.08; N, 12.51. Found: C, 50.85; H, 5.99, N, 12.10. NMR: ${ }^{1} \mathrm{H}$ NMR $\left(500 \mathrm{MHz}\right.$, THF- $d_{8}, 333$ K) $\delta 1.77\left(\mathrm{~s}, 15 \mathrm{H}, \mathrm{C}_{5}\left(\mathrm{CH}_{3}\right)_{5}\right), 3.93\left(\mathrm{~s}, 6 \mathrm{H}, \mathrm{NCH}_{3}\right), 5.26,5.76(\mathrm{~d}$, ${ }^{2} J_{\mathrm{HH}}=11.6 \mathrm{~Hz}, 1 \mathrm{H}$ each, $\left.\mathrm{CH}_{a} H_{\mathrm{b}}\right), 6.95,6.99(\mathrm{~s} \mathrm{br}, 2 \mathrm{H}$ each, $\mathrm{CH}=$ $\mathrm{CH}) ;{ }^{13} \mathrm{C}\left\{{ }^{1} \mathrm{H}\right\} \quad$ NMR $\left(125.7 \mathrm{MHz}\right.$, THF- $\left.d_{8}, 333 \mathrm{~K}\right) \quad \delta 10.3$ $\left(\mathrm{C}_{5}\left(\mathrm{CH}_{3}\right)_{5}\right), 36.8\left(\mathrm{NCH}_{3}\right), 61.8\left(\mathrm{CH}_{2}\right), 83.3\left(\mathrm{C}_{5}\left(\mathrm{CH}_{3}\right)_{5}\right), 118.5$, $121.4(\mathrm{CH}=\mathrm{CH}), \mathrm{RuC}$ not observed.

$[\mathrm{Cp} * \mathrm{Ru}(\mathrm{MeCN})(\mathrm{L})]\left[\mathrm{BPh}_{4}\right] 3$. Compound $2(0.45 \mathrm{~g}$, ca. $1 \mathrm{mmol})$ was dissolved in $\mathrm{MeOH}(15 \mathrm{~mL})$ under dinitrogen. Acetonitrile (1 $\mathrm{mL})$ and solid $\mathrm{NaBPh}_{4}(0.45 \mathrm{~g}, 1.3 \mathrm{mmol})$ was added. A yellow precipitate was formed. The mixture was stirred at room temperature for $1 \mathrm{~h}$. The mixture was filtered, and the yellow solids washed with ethanol and petroleum ether and dried in vacuo. The crude product was dissolved in acetonitrile, and the solution filtered through Celite. The solution was layered with $\mathrm{MeOH}$. Slow diffusion afforded wellformed amber crystals, suitable for X-ray analysis. Yield: $0.59 \mathrm{~g}, 77 \%$. Calcd for $\mathrm{C}_{45} \mathrm{H}_{50} \mathrm{~N}_{5} \mathrm{BRu}$ : C, 69.94; H, 6.52; N, 9.06. Found: C, 70.02; $\mathrm{H}, 6.54, \mathrm{~N}, 9.00$. IR: $\nu(\mathrm{CN}) 2252 \mathrm{~cm}^{-1}$. NMR: ${ }^{1} \mathrm{H}$ NMR $(500 \mathrm{MHz}$, $\left.\mathrm{CD}_{3} \mathrm{CN}, 298 \mathrm{~K}\right) \delta 1.57\left(\mathrm{~s}, 15 \mathrm{H}, \mathrm{C}_{5}\left(\mathrm{CH}_{3}\right)_{5}\right), 2.15\left(\mathrm{~s}, 3 \mathrm{H}, \mathrm{CH}_{3} \mathrm{CN}\right)$, $3.77\left(\mathrm{~s}, 6 \mathrm{H}, \mathrm{NCH}_{3}\right), 5.31,5.80\left(\mathrm{~d},{ }^{2} J_{\mathrm{HH}}=13.5 \mathrm{~Hz}, 1 \mathrm{H}\right.$ each, $\left.\mathrm{CH}_{a} H_{\mathrm{b}}\right)$, 7.10, $7.19\left(\mathrm{~d},{ }^{3} \mathrm{~J}_{\mathrm{HH}}=2.1 \mathrm{~Hz}, 2 \mathrm{H}\right.$ each, $\left.\mathrm{CH}=\mathrm{CH}\right) ;{ }^{13} \mathrm{C}\left\{{ }^{1} \mathrm{H}\right\} \mathrm{NMR}$ $\left(125.7 \mathrm{MHz}, \mathrm{CD}_{3} \mathrm{CN}, 298 \mathrm{~K}\right) \delta 10.8\left(\mathrm{C}_{5}\left(\mathrm{CH}_{3}\right)_{5}\right), 37.1\left(\mathrm{NCH}_{3}\right), 62.3$ $\left(\mathrm{CH}_{2}\right), 86.93\left(\mathrm{C}_{5}\left(\mathrm{CH}_{3}\right)_{5}\right), 121.6,126.6(\mathrm{CH}=\mathrm{CH}), 193.0(\mathrm{RuC})$.

$\left[\{\mathrm{Cp} * \mathrm{Ru}(\mathrm{L})\}_{2}\left(\boldsymbol{\mu}-\mathrm{N}_{2}\right)\right]\left[\mathrm{BPh}_{4}\right]_{2}$ 4. To a mixture of $2(1.77 \mathrm{~g}, 3.96$ mmol) and $\mathrm{NaBPh}_{4}(1.9 \mathrm{~g}, 5.6 \mathrm{mmol}), \mathrm{MeOH}(20 \mathrm{~mL})$ was added under dinitrogen. A yellow precipitate was formed. The mixture was stirred at room temperature for $12 \mathrm{~h}$. At the end of this time, the suspension was filtered, and the yellow product was washed thoroughly with ethanol and petroleum ether and dried in vacuo. Yield: 2 g, $68 \%$. Calcd for $\mathrm{C}_{86} \mathrm{H}_{94} \mathrm{~N}_{10} \mathrm{~B}_{2} \mathrm{Ru}_{2}$ : C, 69.25; H, 6.35; N, 9.39. Found: $\mathrm{C}, 69.11 ; \mathrm{H}, 6.25, \mathrm{~N}, 9.10$. Raman: $\nu(\mathrm{N} \equiv \mathrm{N}) 2050$ $\mathrm{cm}^{-1}$. NMR: ${ }^{1} \mathrm{H}$ NMR $\left(500 \mathrm{MHz}, \mathrm{CD}_{3} \mathrm{NO}_{2}, 298 \mathrm{~K}\right) \delta 1.71(\mathrm{~s}, 15 \mathrm{H}$, $\left.\mathrm{C}_{5}\left(\mathrm{CH}_{3}\right)_{5}\right), 3.32\left(\mathrm{~s}, 12 \mathrm{H}, \mathrm{NCH}_{3}\right), 5.99,5.52\left(\mathrm{~d},{ }^{2} J_{\mathrm{HH}}=13.0 \mathrm{~Hz}, 2 \mathrm{H}\right.$ each, $\left.\mathrm{CH}_{a} \mathrm{H}_{\mathrm{b}}\right), 7.05,7.31\left(\mathrm{~d},{ }^{3} \mathrm{JH}_{\mathrm{HH}}=2.0 \mathrm{~Hz}, 4 \mathrm{H}\right.$ each, $\left.\mathrm{CH}=\mathrm{CH}\right)$; ${ }^{13} \mathrm{C}\left\{{ }^{1} \mathrm{H}\right\}$ NMR $\left(125.7 \mathrm{MHz}, \mathrm{CD}_{3} \mathrm{NO}_{2}, 298 \mathrm{~K}\right) \delta 11.0\left(\mathrm{C}_{5}\left(\mathrm{CH}_{3}\right)_{5}\right)$, $37.1\left(\mathrm{NCH}_{3}\right), 63.1\left(\mathrm{CH}_{2}\right), 92.1\left(\mathrm{C}_{5}\left(\mathrm{CH}_{3}\right)_{5}\right), 122.9,124.2(\mathrm{CH}=$ $\mathrm{CH}), 185.1(\mathrm{RuC})$.

$[\mathrm{Cp} * \mathrm{Ru}(\mathrm{NO})(\mathrm{L})]\left[\mathrm{BPh}_{4}\right]_{2} \cdot \mathrm{MeNO}_{2}$ 5. Compound 4 (0.3 g 0.2 mmol) was dissolved in $\mathrm{MeNO}_{2}$ and the solution filtered through Celite. The solution was layered with $\mathrm{EtOH}$. On standing at room temperature for several days, well-formed dark orange crystals were obtained. The crystals were filtered off, rinsed with petroleum ether and dried in vacuo. Yield: $0.085 \mathrm{~g}$, $37 \%$. Calcd for $\mathrm{C}_{67} \mathrm{H}_{67} \mathrm{~N}_{5} \mathrm{~B}_{2} \mathrm{ORu}$.
$\mathrm{CH}_{3} \mathrm{NO}_{2}$ : C, 71.52; $\mathrm{H}, 6.18 ; \mathrm{N}, 7.36$. Found: $\mathrm{C}, 71.50 ; \mathrm{H}, 6.16, \mathrm{~N}$, 7.27. IR: $\nu(\mathrm{NO}) 1813 \mathrm{~cm}^{-1}$. NMR: ${ }^{1} \mathrm{H}$ NMR $\left(400 \mathrm{MHz}, \mathrm{CD}_{3} \mathrm{NO}_{2}\right.$, $233 \mathrm{~K}) \delta 2.12\left(\mathrm{~s}, 15 \mathrm{H}, \mathrm{C}_{5}\left(\mathrm{CH}_{3}\right)_{5}\right), 2.89\left(\mathrm{~s}, 6 \mathrm{H}, \mathrm{NCH}_{3}\right), 5.74,6.42$ $\left(\mathrm{d},{ }^{2} J_{\mathrm{HH}}=13.8 \mathrm{~Hz}, 1 \mathrm{H}\right.$ each, $\left.\mathrm{CH}_{a} H_{\mathrm{b}}\right), 7.53,7.64(\mathrm{~s} \mathrm{br}, 1 \mathrm{H}$ each, $\mathrm{CH}=\mathrm{CH}) ;{ }^{13} \mathrm{C}\left\{{ }^{1} \mathrm{H}\right\}$ NMR $\left(101 \mathrm{MHz}, \mathrm{CD}_{3} \mathrm{NO}_{2}, 233 \mathrm{~K}\right) \delta 10.6$ $\left(\mathrm{C}_{5}\left(\mathrm{CH}_{3}\right)_{5}\right), 39.0\left(\mathrm{NCH}_{3}\right), 63.9\left(\mathrm{CH}_{2}\right), 113.2\left(\mathrm{C}_{5}\left(\mathrm{CH}_{3}\right)_{5}\right)$, 127.0, $127.9(\mathrm{CH}=\mathrm{CH}), 159.9(\mathrm{RuC})$.

$\left[\mathrm{Cp} * \mathrm{Ru}\left(\mathrm{H}_{2}\right)(\mathrm{L})\right]\left[\mathrm{BPh}_{4}\right] 6$. Compound 6 was obtained following a synthetic procedure similar to that for 4 , but using an atmosphere of dihydrogen instead of dinitrogen. To a mixture of 2 ( $1.4 \mathrm{~g}, 3.13$ mmol) and $\mathrm{NaBPh}_{4}(1.6 \mathrm{~g}, 4.7 \mathrm{mmol}), \mathrm{MeOH}(20 \mathrm{~mL})$ was added under dihydrogen. An off white precipitate was formed. The mixture was stirred at room temperature under dihydrogen for $12 \mathrm{~h}$. At the end of this time, the suspension was filtered. The white product was washed thoroughly with ethanol and petroleum ether and dried in vacuo. Subsequent manipulations in solution must be performed under an atmosphere of dihydrogen. Yield: $1.46 \mathrm{~g}, 64 \%$. Calcd for $\mathrm{C}_{43} \mathrm{H}_{49} \mathrm{~N}_{4} \mathrm{BRu}$ : C, 70.58; $\mathrm{H}, 6.47$; N, 7.66. Found: C, 70.46; $\mathrm{H}, 6.36$, $\mathrm{N}, 7.45$. NMR: ${ }^{1} \mathrm{H}$ NMR $\left(500 \mathrm{MHz}, \mathrm{CD}_{3} \mathrm{NO}_{2}, 298 \mathrm{~K}\right.$, under dihydrogen) $\delta-7.81\left(\mathrm{~s} \mathrm{br}, 2 \mathrm{H},\left(T_{1}\right)_{\min } \leq 21.4 \mathrm{~ms}, \mathrm{Ru}\left(H_{2}\right)\right), 1.89(\mathrm{~s}$, $\left.15 \mathrm{H}, \mathrm{C}_{5}\left(\mathrm{CH}_{3}\right)_{5}\right), 3.86\left(\mathrm{~s}, 6 \mathrm{H}, \mathrm{NCH}_{3}\right), 5.66,6.99\left(\mathrm{~d},{ }^{2} J_{\mathrm{HH}}=16.0 \mathrm{~Hz}\right.$, $1 \mathrm{H}$ each, $\left.\mathrm{CH}_{a} H_{\mathrm{b}}\right), 7.20,7.29\left(\mathrm{~d},{ }^{3} \mathrm{~J}_{\mathrm{HH}}=2.5 \mathrm{~Hz}, 2 \mathrm{H}\right.$ each, $\mathrm{CH}=$ $\mathrm{CH}) ;{ }^{13} \mathrm{C}\left\{{ }^{1} \mathrm{H}\right\}$ NMR $\left(125.7 \mathrm{MHz}, \mathrm{CD}_{3} \mathrm{NO}_{2}, 298 \mathrm{~K}\right.$, under dihydrogen) $\delta \delta 11.3\left(\mathrm{C}_{5}\left(\mathrm{CH}_{3}\right)_{5}\right), 39.1\left(\mathrm{NCH}_{3}\right), 62.2\left(\mathrm{CH}_{2}\right), 93.9$ $\left(\mathrm{C}_{5}\left(\mathrm{CH}_{3}\right)_{5}\right), 122.3,124.0(\mathrm{CH}=\mathrm{CH}), 185.7(\mathrm{RuC})$.

[Cp*RuH(L)] 7. A mixture of $6(0.63 \mathrm{~g}, 0.86 \mathrm{mmol})$ and $\mathrm{KOBu}^{t}$ $(0.25 \mathrm{~g}, 2.2 \mathrm{mmol}$, excess) was placed under dihydrogen atmosphere. Tetrahydrofuran $(15 \mathrm{~mL})$ was added. The mixture was stirred at room temperature for $1 \mathrm{~h}$. Then, the solvent was removed in vacuo. The residue was extracted with toluene, and the solution filtered through Celite. The solvent was removed in vacuo, and the yellow crystalline solid washed with petroleum ether and dried in vacuo. Yield: $0.29 \mathrm{~g}, 81 \%$. Calcd for $\mathrm{C}_{19} \mathrm{H}_{28} \mathrm{~N}_{4} \mathrm{Ru}$ : C, 55.19; H, 6.82; N, 13.55. Found: C, $55.05 ; \mathrm{H}, 6.96, \mathrm{~N}, 13.15$. IR: $\nu(\mathrm{RuH}) 1780 \mathrm{~cm}^{-1}$. NMR: ${ }^{1} \mathrm{H}$ NMR $\left(400 \mathrm{MHz}, \mathrm{C}_{6} \mathrm{D}_{6}, 298 \mathrm{~K}\right) \delta-11.65(\mathrm{~s}, 1 \mathrm{H}, \mathrm{RuH})$, $2.17\left(\mathrm{~s}, 15 \mathrm{H}, \mathrm{C}_{5}\left(\mathrm{CH}_{3}\right)_{5}\right), 3.48\left(\mathrm{~s}, 6 \mathrm{H}, \mathrm{NCH}_{3}\right), 4.40,5.07\left(\mathrm{~d},{ }^{2} J_{\mathrm{HH}}=\right.$ $12.0 \mathrm{~Hz}, 1 \mathrm{H}$ each, $\left.\mathrm{CH}_{a} \mathrm{H}_{\mathrm{b}}\right), 6.13,6.14\left(\mathrm{~d},{ }^{3} J_{\mathrm{HH}}=2.5 \mathrm{~Hz}, 2 \mathrm{H}\right.$ each, $\mathrm{CH}=\mathrm{CH}) ;{ }^{13} \mathrm{C}\left\{{ }^{1} \mathrm{H}\right\} \quad \mathrm{NMR}\left(101 \mathrm{MHz}, \mathrm{C}_{6} \mathrm{D}_{6}, 298 \mathrm{~K}\right) \delta 11.6$ $\left(\mathrm{C}_{5}\left(\mathrm{CH}_{3}\right)_{5}\right), 37.6\left(\mathrm{NCH}_{3}\right), 61.7\left(\mathrm{CH}_{2}\right), 86.2\left(\mathrm{C}_{5}\left(\mathrm{CH}_{3}\right)_{5}\right)$, 116.5.1, $118.7(\mathrm{CH}=\mathrm{CH}), 207.5(\mathrm{RuC})$.

$\left[\mathrm{Cp} * \mathrm{Ru}\left(\mathrm{CH}_{2}=\mathrm{CHR}\right)(\mathrm{L})\right]\left[\mathrm{BPh}_{4}\right](\mathrm{R}=\mathrm{H}$ 8a, COOMe 8b). Compounds $\mathbf{8 a}, \mathbf{b}$ were generated in solution either by bubbling ethylene (for $\mathbf{8 a}$ ) or adding an excess of methyl acrylate (for $\mathbf{8 b}$ ) to a solution of 4 in $\mathrm{CD}_{3} \mathrm{NO}_{2}$ under argon. 8a: NMR: ${ }^{1} \mathrm{H}$ NMR (500 $\left.\mathrm{MHz}, \mathrm{CD}_{3} \mathrm{NO}_{2}, 298 \mathrm{~K}\right) \delta 1.64\left(\mathrm{~s}, 15 \mathrm{H}, \mathrm{C}_{5}\left(\mathrm{CH}_{3}\right)_{5}\right), 2.14(\mathrm{~s}, 4 \mathrm{H}$, $\left.\mathrm{C}_{2} \mathrm{H}_{4}\right), 3.95\left(\mathrm{~s}, 6 \mathrm{H}, \mathrm{NCH}_{3}\right), 5.93,5.60\left(\mathrm{~d},{ }^{2} J_{\mathrm{HH}}=12.5 \mathrm{~Hz}, 1 \mathrm{H}\right.$ each, $\left.\mathrm{CH}_{a} \mathrm{H}_{\mathrm{b}}\right), 7.27(\mathrm{br}, 4 \mathrm{H}, \mathrm{CH}=\mathrm{CH}) ;{ }^{13} \mathrm{C}\left\{{ }^{1} \mathrm{H}\right\} \operatorname{NMR}(125.7 \mathrm{MHz}$, $\left.\mathrm{CD}_{3} \mathrm{NO}_{2}, 298 \mathrm{~K}\right) \delta 10.1\left(\mathrm{C}_{5}\left(\mathrm{CH}_{3}\right)_{5}\right), 39.0\left(\mathrm{NCH}_{3}\right), 47.2\left(\mathrm{C}_{2} \mathrm{H}_{4}\right)$, $61.7\left(\mathrm{CH}_{2}\right), 94.3\left(\mathrm{C}_{5}\left(\mathrm{CH}_{3}\right)_{5}\right), 122.6,125.3(\mathrm{CH}=\mathrm{CH}), 185.8(\mathrm{RuC})$. 8b: NMR: ${ }^{1} \mathrm{H}$ NMR $\left(500 \mathrm{MHz}, \mathrm{CD}_{3} \mathrm{NO}_{2}, \quad 298 \mathrm{~K}\right) \quad \delta \quad 1.69$ $\left(\mathrm{C}_{5}\left(\mathrm{CH}_{3}\right)_{5}\right), 2.70\left(\mathrm{~d},{ }^{3} \mathrm{~J}_{\mathrm{HHa}}=8.5 \mathrm{~Hz}, 1 \mathrm{H}, \mathrm{CH}=\mathrm{CH}_{\mathrm{a}} \mathrm{H}_{\mathrm{b}}\right), 2.76(\mathrm{~d}$, $\left.{ }^{3} J_{\mathrm{HHb}}=10.0 \mathrm{~Hz}, 1 \mathrm{H}, \mathrm{CH}=\mathrm{CH}_{\mathrm{a}} H_{\mathrm{b}}\right), 2.86\left(\mathrm{~s}, 3 \mathrm{H}, \mathrm{COOCH}_{3}\right), 3.02$ $\left(\mathrm{dd},{ }^{3} \mathrm{~J}_{\mathrm{HHa}}=8.5 \mathrm{~Hz},{ }^{3} \mathrm{~J}_{\mathrm{HHb}}=10.0 \mathrm{~Hz}, 1 \mathrm{H}, \mathrm{CH}=\mathrm{CH}_{\mathrm{a}} \mathrm{H}_{\mathrm{b}}\right), 3.97,3.98$ $\left(\mathrm{s}, 3 \mathrm{H}\right.$ each, $\left.\mathrm{NCH}_{3}\right), 5.65,5.96\left(\mathrm{~d},{ }^{2} J_{\mathrm{HH}}=12.5 \mathrm{~Hz}, 1 \mathrm{H}\right.$ each, $\left.\mathrm{CH}_{a} \mathrm{H}_{\mathrm{b}}\right), 7.18,7.22,7.36(\mathrm{~d}, 4 \mathrm{H}, \mathrm{CH}=\mathrm{CH}) ;{ }^{13} \mathrm{C}\left\{{ }^{1} \mathrm{H}\right\}$ NMR $(125.7$ $\left.\mathrm{MHz}, \mathrm{CD}_{3} \mathrm{NO}_{2}, 298 \mathrm{~K}\right) \delta 10.3\left(\mathrm{C}_{5}\left(\mathrm{CH}_{3}\right)_{5}\right), 39.3,39.6\left(\mathrm{NCH}_{3}\right), 50.2$ $\left(\mathrm{CH}=\mathrm{CH}_{2}\right), 51.4\left(\mathrm{COOCH}_{3}\right), 52.1\left(\mathrm{CH}=\mathrm{CH}_{2}\right), 62.9\left(\mathrm{CH}_{2}\right), 96.2$ $\left(\mathrm{C}_{5}\left(\mathrm{CH}_{3}\right)_{5}\right), 122.5, \quad 123.5,125.2,125.6(\mathrm{CH}=\mathrm{CH}), \quad 177.2$ $\left(\mathrm{COOCH}_{3}\right), 180.8,183.9(\mathrm{RuC})$.

$[\mathrm{Cp} * \mathrm{Ru}=\mathrm{CHPh}(\mathrm{L})]\left[\mathrm{BPh}_{4}\right]$ 9. To solid $4(0.25 \mathrm{~g}, 0.17 \mathrm{mmol})$ or 6 $(0.25 \mathrm{~g}, 0.34 \mathrm{mmol})$ under argon, tetrahydrofuran $(10 \mathrm{~mL})$ and freshly prepared phenyldiazomethane ( $2 \mathrm{mmol}$ in toluene, excess) was added at room temperature. Dinitrogen evolution was observed. After $1 \mathrm{~h}$, the solvent was removed in vacuo, and the residue washed with diethyl ether and petroleum ether. Recrystallization from THF/ petroleum ether yielded a dark red microcrystalline solid, which was filtered off, washed with petroleum ether, and dried in vacuo. Yield: 0.19 g, $70 \%$. Calcd for $\mathrm{C}_{50} \mathrm{H}_{53} \mathrm{~N}_{4} \mathrm{BRu}$ : C, 73.07; H, 6.50; N, 6.82. Found: C, 73.15; H, 6.39, N, 6.85. NMR: ${ }^{1} \mathrm{H}$ NMR (500 MHz, $\left.\mathrm{CD}_{3} \mathrm{NO}_{2}, 298 \mathrm{~K}\right) \delta 1.85\left(\mathrm{~s}, 15 \mathrm{H}, \mathrm{C}_{5}\left(\mathrm{CH}_{3}\right)_{5}\right), 2.87\left(\mathrm{~s}, 6 \mathrm{H}, \mathrm{NCH}_{3}\right)$, 
6.29, $5.63\left(\mathrm{~d},{ }^{2} J_{\mathrm{HH}}=12.7 \mathrm{~Hz}, 1 \mathrm{H}\right.$ each, $\left.\mathrm{CH}_{a} H_{\mathrm{b}}\right), 7.39,7.42\left(\mathrm{~d},{ }^{3} J_{\mathrm{HH}}=\right.$ $2.0 \mathrm{~Hz}, 2 \mathrm{H}$ each, $\mathrm{CH}=\mathrm{CH}), 7.61,7.41\left(\mathrm{~m}, 5 \mathrm{H}, \mathrm{C}_{6} \mathrm{H}_{5}\right), 15.7(\mathrm{~s}, 1 \mathrm{H}$, $\mathrm{Ru}=\mathrm{CHPh}) ;{ }^{13} \mathrm{C}\left\{{ }^{1} \mathrm{H}\right\} \mathrm{NMR}\left(125.7 \mathrm{MHz}, \mathrm{CD}_{3} \mathrm{NO}_{2}, 298 \mathrm{~K}\right) \delta 10.5$ $\left(\mathrm{C}_{5}\left(\mathrm{CH}_{3}\right)_{5}\right), 37.2\left(\mathrm{NCH}_{3}\right), 63.9\left(\mathrm{CH}_{2}\right), 102.9\left(\mathrm{C}_{5}\left(\mathrm{CH}_{3}\right)_{5}\right), 122.6$, $123.9(\mathrm{CH}=\mathrm{CH}), 127.8,129.6,130.4,153.9\left(C_{6} \mathrm{H}_{5}\right), 184.0(\mathrm{RuC})$, $287.2(\mathrm{Ru}=\mathrm{CHPh})$.

$\left[\mathrm{Cp} * \mathrm{Ru}=\mathrm{C}=\mathrm{C}=\mathrm{CPh}_{2}(\mathrm{~L})\right]\left[\mathrm{BPh}_{4}\right]$ 10. To a mixture of $2(0.15 \mathrm{~g}$, $0.33 \mathrm{mmol}), \mathrm{NaBPh}_{4}(0.3 \mathrm{~g}$, excess $)$ and $\mathrm{HC} \equiv \mathrm{CC}(\mathrm{OH}) \mathrm{Ph}_{2}(0.1 \mathrm{~g}$, $0.48 \mathrm{mmol}) \mathrm{MeOH}(15 \mathrm{~mL})$ was added. An orange precipitate was immediately formed. The mixture was stirred overnight at $60{ }^{\circ} \mathrm{C}$. During this time, the color of the mixture changed to dark red. The mixture was cooled to room temperature and then to $-20{ }^{\circ} \mathrm{C}$. The dark red crystalline precipitate was filtered off, washed with ethanol and petroleum ether, and dried in vacuo. Yield: $0.22 \mathrm{~g}, 72 \%$. Calcd for $\mathrm{C}_{58} \mathrm{H}_{57} \mathrm{~N}_{4} \mathrm{BRu}$ : C, 75.56; H, 6.23; N, 6.08. Found: C, 74.61; H, 6.29, $\mathrm{N}$, 6.05. IR: $\nu(\mathrm{C}=\mathrm{C}=\mathrm{C}) 1879 \mathrm{~cm}^{-1}$. NMR: ${ }^{1} \mathrm{H}$ NMR $(500 \mathrm{MHz}$, acetone- $\left.d_{6}, 298 \mathrm{~K}\right) \delta 1.88\left(\mathrm{~s}, 15 \mathrm{H}, \mathrm{C}_{5}\left(\mathrm{CH}_{3}\right)_{5}\right), 3.46\left(\mathrm{~s}, 6 \mathrm{H}, \mathrm{NCH}_{3}\right)$, $5.62,6.34\left(\mathrm{~d},{ }^{2} J_{\mathrm{HH}}=12.7 \mathrm{~Hz}, 1 \mathrm{H}\right.$ each, $\left.\mathrm{CH}_{a} H_{\mathrm{b}}\right), 7.22,7.38\left(\mathrm{~d},{ }^{3} J_{\mathrm{HH}}=\right.$ $2.0 \mathrm{~Hz}, 2 \mathrm{H}$ each, $\mathrm{CH}=\mathrm{CH}), 7.28\left(\mathrm{t},{ }^{3} J_{\mathrm{HH}}=8.1 \mathrm{~Hz}, 4 \mathrm{H}\right), 7.54(\mathrm{t}$, $\left.{ }^{3} J_{\mathrm{HH}}=7.4 \mathrm{~Hz}, 2 \mathrm{H}\right), 7.69\left(\mathrm{~d},{ }^{3} J_{\mathrm{HH}}=8.1 \mathrm{~Hz}\right)\left(\mathrm{C}_{6} \mathrm{H}_{5}\right) ;{ }^{13} \mathrm{C}\left\{{ }^{1} \mathrm{H}\right\} \mathrm{NMR}$ $\left(125.7 \mathrm{MHz}\right.$, acetone- $\left.d_{6}, 298 \mathrm{~K}\right) \delta 10.7\left(\mathrm{C}_{5}\left(\mathrm{CH}_{3}\right)_{5}\right), 37.6\left(\mathrm{NCH}_{3}\right)$, $62.9\left(\mathrm{CH}_{2}\right), 101.8\left(\mathrm{C}_{5}\left(\mathrm{CH}_{3}\right)_{5}\right), 122.2,123.5(\mathrm{CH}=\mathrm{CH}), 128.7$, 129.3, 129.6, $145.9\left(\mathrm{C}_{6} \mathrm{H}_{5}\right), 139.8(\mathrm{RuC}=\mathrm{C}=\mathrm{C}), 178.0(\mathrm{RuC})$, $225.6(\mathrm{Ru}=\mathrm{C}=\mathrm{C}=\mathrm{C}), 274.9(\mathrm{RuC}=\mathrm{C}=\mathrm{C})$.

General Procedure for the Catalytic Transfer Hydrogenation of Carbonyl Compounds. To a solution of the corresponding ruthenium catalysts 3,4 , or $6(0.005 \mathrm{mmol})$ and $\mathrm{KOH}(0.05 \mathrm{mmol})$ in degassed isopropanol $(1 \mathrm{~mL})$ under argon, the corresponding ketones 11-22 or aldehydes 23-25 (1 mmol) were added. The reaction mixture was stirred at $80{ }^{\circ} \mathrm{C}$ for $2 \mathrm{~h}$ and then evaluated by TLC and GC-MS. Solvent was evaporated under reduced pressure and the crude was purified by silica gel column using petroleum ether and ethyl acetate mixtures to afford compounds 11a-25a. Full characterization data for each of the isolated organic products are given in the Supporting Information.

Crystal Structure Analysis. Crystals suitable for X-ray structural determination were mounted on glass fibers and then transferred to a Bruker Smart CCD three-circle diffractometer with a sealed-tube source and graphite-monochromated Mo K $\alpha$ radiation $(\lambda=0.71073$ $\AA ̊$ ) at the Servicio Central de Ciencia y Tecnologia de la Universidad de Cadiz (1) or Servicios Técnicos de Investigación de la Universidad de Alicante (3 and 5). In each case, three ( 3 and 5 ) at $298 \mathrm{~K}$ or four at $100 \mathrm{~K}(1)$ sets of frames were recorded over a hemisphere of the reciprocal space by $\omega$ scans with $\delta(\omega)=0.30^{\circ}$ and exposure of 10 to $20 \mathrm{~s}$ per frame. In the case of 3 and $\mathbf{5}$, an additional run at $\phi=0^{\circ}$ of 100 frames was collected to improve redundancy. The diffraction frames were integrated using the program SAINT ${ }^{43}$ and the integrated intensities were corrected for Lorentz-polarization effects with SADABS. ${ }^{44}$ An insignificant crystal decay correction was also applied. The structure of $\mathbf{1}$ was solved by Patterson method, and direct methods were used for $\mathbf{3}$ and $\mathbf{5}$. All structures were refined on $F^{2}$ by full-matrix least-squares (SHELX97) ${ }^{45}$ using all unique data. All nonhydrogen atoms were refined anisotropically. Hydrogen atoms were placed at idealized positions and refined as rigid atoms. ORTEP was used for plotting. ${ }^{46}$ CCDC 1483010, 2056271-2056272 contain supplementary crystallographic data for this paper. These data can be obtained free of charge from The Cambridge Crystallographic Data Centre via www.ccdc.cam.ac.uk/data_request/cif.

\section{ASSOCIATED CONTENT}

\section{SI Supporting Information}

The Supporting Information is available free of charge at https://pubs.acs.org/doi/10.1021/acs.organomet.1c00045.

General procedure for the catalytic transfer hydrogenation of carbonyl compounds and characterization data for compounds 11a-25a; ${ }^{1} \mathrm{H}$ and ${ }^{13} \mathrm{C}\left\{{ }^{1} \mathrm{H}\right\}$ NMR spectra for compounds 2-10 (Figures $\mathrm{S} 1-\mathrm{S} 10$ ) and 11a-25a (Figures S11-S23); Crystal data and exper- imental details for the crystal structure determination (Table S1) (PDF)

\section{Accession Codes}

CCDC 1483010 and 2056271-2056272 contain the supplementary crystallographic data for this paper. These data can be obtained free of charge via www.ccdc.cam.ac.uk/data_request/ cif, or by emailing data_request@ccdc.cam.ac.uk, or by contacting The Cambridge Crystallographic Data Centre, 12 Union Road, Cambridge CB2 1EZ, UK; fax: +44 1223336033.

\section{AUTHOR INFORMATION}

\section{Corresponding Author}

Manuel Jiménez-Tenorio - Departamento de Ciencia de los Materiales e Ingeniería Metalúrgica y Química InorgánicaINBIO, Facultad de Ciencias, Universidad de Cádiz, 11510 Puerto Real, Cádiz, Spain; @ orcid.org/0000-0003-40884958; Email: manuel.tenorio@uca.es

\section{Authors}

José Manuel Botubol-Ares - Departamento de Química Orgánica-INBIO, Facultad de Ciencias, Universidad de Cádiz, 11510 Puerto Real, Cádiz, Spain; 이이.org/00000002-2312-612X

Safa Cordón-Ouahhabi - Departamento de Química Orgánica-INBIO, Facultad de Ciencias, Universidad de Cádiz, 11510 Puerto Real, Cádiz, Spain

Zakaria Moutaoukil - Departamento de Química OrgánicaINBIO, Facultad de Ciencias, Universidad de Cádiz, 11510 Puerto Real, Cádiz, Spain

Isidro G. Collado - Departamento de Química OrgánicaINBIO, Facultad de Ciencias, Universidad de Cádiz, 11510 Puerto Real, Cádiz, Spain; 이이.org/0000-0002-86120593

M. Carmen Puerta - Departamento de Ciencia de los Materiales e Ingeniería Metalúrgica y Química InorgánicaINBIO, Facultad de Ciencias, Universidad de Cádiz, 11510 Puerto Real, Cádiz, Spain

Pedro Valerga - Departamento de Ciencia de los Materiales e Ingeniería Metalúrgica y Química Inorgánica-INBIO, Facultad de Ciencias, Universidad de Cádiz, 11510 Puerto Real, Cádiz, Spain

Complete contact information is available at: https://pubs.acs.org/10.1021/acs.organomet.1c00045

\section{Notes}

The authors declare no competing financial interest.

\section{ACKNOWLEDGMENTS}

This research was supported by "Programa de fomento e impulso de la investigación y la transferencia” from University of Cadiz (PR2017-047), and by Junta de Andalucía (PAIDI FQM188 and FQM 295). We wish to thank Dr. Miguel Angel Centeno, from the ICMSE-CSIC (Sevilla) for recording the Raman spectra, and Rocío González Moya for efficient assistance in laboratory experiments.

\section{REFERENCES}

(1) For selected reviews, see: (a) Stefane, B.; Pozgan, F. MetalCatalysed Transfer Hydrogenation of Ketones. Top. Curr. Chem. 2016, 374, 18. (b) Echeverria, P.-G.; Ayad, T.; Phansavath, P.; Ratovelomanana-Vidal, V. Recent Developments in Asymmetric Hydrogenation and Transfer Hydrogenation of Ketones and Imines through Dynamic Kinetic Resolution. Synthesis 2016, 48, 2523-2539. 
(c) Foubelo, F.; Nájera, C.; Yus, M. Catalytic asymmetric transfer hydrogenation of ketones: recent advances. Tetrahedron: Asymmetry 2015, 26, 769-790. (d) Blaser, H.-U.; Malan, C.; Pugin, B.; Spindler, F.; Steiner, H.; Studer, M. Selective Hydrogenation for Fine Chemicals: Recent Trends and New Developments. Adv. Synth. Catal. 2003, 345, 103-151. (e) Samec, J. S. M.; Bäckvall, J.-E.; Andersson, P. G.; Brandt, P. Mechanistic aspects of transition metalcatalyzed hydrogen transfer reactions. Chem. Soc. Rev. 2006, 35, 237248.

(2) (a) Andersson, P. G., Munslow, I. J., Eds.; Modern Reduction Methods; Wiley-VCH: Weinheim, Germany, 2008. DOI: 10.1002/ 9783527622115. (b) Hynes, J. T., Klinman, J. P., Limbach, H.-H., Schowen, R. L., Eds.; Hydrogen Transfer Reactions; Wiley-VCH: Weinheim, Germany, 2007; Vols. 1-4. DOI: 10.1002/ 9783527611546.

(3) Andrushko, N., Andrushko, V., Eds. Stereoselective Synthesis of Drugs and Natural Products; John Wiley \& Sons, Inc.: Hoboken, NJ, 2013; pp 909-960. DOI: 10.1002/9781118596784.

(4) Wang, D.; Deraedt, C.; Ruiz, J.; Astruc, D. Sodium hydroxidecatalyzed transfer hydrogenation of carbonyl compounds and nitroarenes using ethanol or isopropanol as both solvent and hydrogen donor. J. Mol. Catal. A: Chem. 2015, 400, 14-21.

(5) Campaña, A. G.; Estévez, R. E.; Fuentes, N.; Robles, R.; Cuerva, J. M.; Buñuel, E.; Cárdenas, D.; Oltra, J. E. Unprecedented Hydrogen Transfer from Water to Alkenes and Alkynes Mediated by $\mathrm{Ti}^{\mathrm{III}}$ and Late Transition Metals. Org. Lett. 2007, 9, 2195-2198.

(6) Koike, T.; Ikariya, T. Mechanistic Aspects of Formation of Chiral Ruthenium Hydride Complexes from 16-Electron Ruthenium Amide Complexes and Formic Acid: Facile Reversible Decarboxylation and Carboxylation. Adv. Synth. Catal. 2004, 346, 37-41.

(7) (a) Yoshida, M.; Hirahata, R.; Inoue, T.; Shimbayashi, T.; Fujita, K.-I. Iridium-Catalyzed Transfer Hydrogenation of Ketones and Aldehydes Using Glucose as a Sustainable Hydrogen Donor. Catalysts 2019, 9, 503. (b) Sato, Y.; Kayaki, Y.; Ikariya, T. Comparative Study of Bifunctional Mononuclear and Dinuclear Amidoiridium Complexes with Chiral C-N Chelating Ligands for the Asymmetric Transfer Hydrogenation of Ketones. Chem. - Asian J. 2016, 11, 2924-2931. (c) Tian, C.; Gong, L.; Meggers, E. Chiral-at-metal iridium complex for efficient enantioselective transfer hydrogenation of ketones. Chem. Commun. 2016, 52, 4207-4210. (d) Volpe, A.; Baldino, S.; Tubaro, C.; Baratta, W.; Basato, M.; Graiff, C. Dinuclear Di(N-heterocyclic carbene) Iridium(III) Complexes as Catalysts in Transfer Hydrogenation. Eur. J. Inorg. Chem. 2016, 2016, 247-251. (e) GomezLopez, J. L.; Chávez, D.; Parra-Hake, M.; Royappa, A. T.; Rheingold, A. L.; Grotjahn, D. B.; Miranda-Soto, V. Synthesis and Reactivity of Bis(protic N-heterocyclic carbene)iridium(III) Complexes. Organometallics 2016, 35, 3148-3153.

(8) (a) Mohan, N.; Ramesh, R. Transfer hydrogenation of ketones catalysed by half-sandwich ( $\eta^{6}$-p-cymene) ruthenium(II) complexes incorporating benzoylhydrazone ligands. Appl. Organomet. Chem. 2017, 31, e3648. (b) Ramesh, M.; Venkatachalam, G. Half-Sandwich $\left(\eta^{6}-\mathrm{p}-\right.$ Cymene) Ruthenium(II) complexes bearing 5-Amino-1Methyl-3-Phenylpyrazole Schiff base ligands: Synthesis, structure and catalytic transfer hydrogenation of ketones. J. Organomet. Chem. 2019, 880, 47-55. (c) Amenuvor, G.; Obuah, C.; Nordlander, E.; Darkwa, J. Novel pyrazolylphosphite- and pyrazolylphosphiniteruthenium(II) complexes as catalysts for hydrogenation of acetophenone. Dalton Trans. 2016, 45, 13514-13524. (d) Hey, D. A.; Sauer, M. J.; Fischer, P. J.; Esslinger, E-M. H. J.; Kuehn, F. E.; Baratta, W. Acetate Acetylacetonate Ampy Ruthenium(II) Complexes as Efficient Catalysts for Ketone Transfer Hydrogenation. ChemCatChem 2020, 12, 3537-3544. (e) Liu, T.; Wu, K.; Wang, L.; Fan, H.; Zhou, Y.-G.; $\mathrm{Yu}, \mathrm{Z}$. Assembled Multinuclear Ruthenium(II)-NNNN Complexes: Synthesis, Catalytic Properties, and DFT Calculations. Organometallics 2020, 39, 93-104.

(9) (a) Deshpande, S. H.; Shende, V. S.; Shingote, S. K.; Chakravarty, D.; Puranik, V. G.; Chaudhari, R. V.; Kelkar, A. A. Rhodium complex with unsymmetrical vicinal diamine ligand: excellent catalyst for asymmetric transfer hydrogenation of ketones.
RSC Adv. 2015, 5, 51722-51729. (b) Ibarra-Vazquez, M. F.; Alvarado-Rodriguez, J. G.; Esqueda, A. C.; Rangel-Salas, I. I.; Serrano, O. Synthesis, structural characterization, and activity on the transfer hydrogenation reaction of dimesitylacetonate piano stool organometallic complexes of $\mathrm{Ru}(\mathrm{II}), \mathrm{Rh}(\mathrm{III})$, and $\mathrm{Ir}(\mathrm{III})$. J. Mol. Struct. 2019, 1191, 52-58. (c) Günnaz, S.; Gökçe, A. G.; Türkmen, H. Synthesis of bimetallic complexes bridged by 2,6-bis(benzimidazol2-yl) pyridine derivatives and their catalytic properties in transfer hydrogenation. Dalton Trans. 2018, 47, 17317-17328.

(10) Wang, D.; Astruc, D. The Golden Age of Transfer Hydrogenation. Chem. Rev. 2015, 115, 6621-6686.

(11) (a) Bauri, S.; Donthireddy, S. N. R.; Illam, P. M.; Rit, A. Effect of Ancillary Ligand in Cyclometalated $\mathrm{Ru}(\mathrm{II})-\mathrm{NHC}$-Catalyzed Transfer Hydrogenation of Unsaturated Compounds. Inorg. Chem. 2018, 57, 14582-14593. (b) Peris, E. Smart N-Heterocyclic Carbene Ligands in Catalysis. Chem. Rev. 2018, 118, 9988-10031.

(12) (a) Arduengo, A. J.; Bertrand, G. Carbenes Introduction. Chem. Rev. 2009, 109, 3209-3210. (b) Nelson, D. J.; Nolan, S. P. Quantifying and understanding the electronic properties of $\mathrm{N}$ heterocyclic carbenes. Chem. Soc. Rev. 2013, 42, 6723-6753. (c) Hopkinson, M. N.; Richter, C.; Schedler, M.; Glorius, F. An overview of N-heterocyclic carbenes. Nature 2014, 510, 485-496. (d) Poyatos, M.; Mata, J. A.; Peris, E. Complexes with Poly(Nheterocyclic carbene) Ligands: Structural Features and Catalytic Applications. Chem. Rev. 2009, 109, 3677-3707.

(13) (a) Djukic, J.-P.; Sortais, J.-B.; Barloy, L.; Pfeffer, M. Cycloruthenated Compounds - Synthesis and Applications. Eur. J. Inorg. Chem. 2009, 2009, 817-853. (b) Mata, J. A.; Poyatos, M.; Peris, E. Structural and catalytic properties of chelating bis- and trisN-heterocyclic carbenes. Coord. Chem. Rev. 2007, 251, 841-859.

(14) (a) Gardiner, M. G.; Ho, C. C. Recent advances in bidentate bis(N-heterocyclic carbene) transition metal complexes and their applications in metal-mediated reactions. Coord. Chem. Rev. 2018, 375, 373-388. (b) Röther, A.; Kretschmer, R. Syntheses of Bis(Nheterocyclic carbene)s and their application in main-group chemistry. J. Organomet. Chem. 2020, 918, 121289.

(15) (a) Nolan, S. P., Ed.; N-Heterocyclic Carbenes in Synthesis; Wiley-VCH: Weinheim, 2006. (b) Glorius, F., Ed.; N-Heterocyclic Carbenes in Transition Metal Catalysis; Springer-Verlag: Berlin, 2007. (c) Díez-González, S., Ed.; N-Heterocyclic Carbenes: From Laboratory Curiosities to Efficient Synthetic Tools; RSC Publishing: Cambridge, 2010. DOI: 10.1039/9781849732161. (d) Cazin, C. S. J., Ed.; NHeterocyclic Carbenes in Transition Metal Catalysis and Organocatalysis; Springeer: Dordrecht, 2011. (e) Nolan, S. P., Ed.; N-Heterocyclic Carbenes-Effective Tools for Organometallic Synthesis; Wiley-VCH: Weinheim, 2014. (f) Díez-González, S., Ed.; N-Heterocyclic Carbenes: From Laboratory Curiosities to Efficient Synthetic Tools, 2nd ed.; RSC Publishing: Cambridge, 2016. DOI: 10.1039/9781782626817.

(16) (a) Illam, P. M.; Donthireddy, S. N. R.; Chakrabartty, S.; Rit, A. Heteroditopic $\mathrm{Ru}(\mathrm{II})$ - and $\mathrm{Ir}(\mathrm{III})-\mathrm{NHC}$ Complexes with Pendant 1,2,3-Triazole/Triazolylidene Groups: Stereoelectronic Impact on Transfer Hydrogenation of Unsaturated Compounds. Organometallics 2019, 38, 2610-2623. (b) Balamurugan, G.; Ramesh, R.; Malecki, J. G. Cyclometalated $\mathrm{Ru}(\mathrm{II})-\mathrm{NHC}$ Complexes as Effective Catalysts for Transfer Hydrogenation: Influence of Wingtip Group on Catalytic Outcome. ChemistrySelect 2017, 2, 10603-10608. (c) Hey, D. A.; Reich, R. M.; Baratta, W.; Kühn, F. E. Current advances on ruthenium(II) N-heterocyclic carbenes in hydrogenation reactions. Coord. Chem. Rev. 2018, 374, 114-132 and references therein.

(17) Fernandez, F. E.; Puerta, M. C.; Valerga, P. Half-Sandwich Ruthenium(II) Picolyl-NHC Complexes: Synthesis, Characterization, and Catalytic Activity in Transfer Hydrogenation Reactions. Organometallics 2011, 30, 5793-5802.

(18) Fernandez, F. E.; Puerta, M. C.; Valerga, P. Ruthenium(II) Picolyl-NHC Complexes: Synthesis, Characterization, and Catalytic Activity in Amine N-alkylation and Transfer Hydrogenation Reactions. Organometallics 2012, 31, 6868-6879. 
(19) Horn, S.; Gandolfi, C.; Albrecht, M. Transfer Hydrogenation of Ketones and Activated Olefins Using Chelating NHC Ruthenium Complexes. Eur. J. Inorg. Chem. 2011, 2011, 2863-2868.

(20) Gandolfi, C.; Heckenroth, M.; Neels, A.; Laurenczy, G.; Albrecht, M. Chelating NHC Ruthenium(II) Complexes as Robust Homogeneous Hydrogenation Catalysts. Organometallics 2009, 28, 5112-5121.

(21) Jiménez-Tenorio, M.; Puerta, M. C.; Valerga, P. Activation of Propargyl Alcohols by $\mathrm{TpRu}$ Complexes Bearing a Bidentate NHC Ligand. Organometallics 2016, 35, 388-399.

(22) Schuster, O.; Yang, L.; Raubenheimer, H. G.; Albrecht, M. Beyond Conventional N-Heterocyclic Carbenes: Abnormal, Remote, and Other Classes of NHC Ligands with Reduced Heteroatom Stabilization. Chem. Rev. 2009, 109, 3445-3478.

(23) Fernandez, F. E.; Puerta, M. C.; Valerga, P. Picolyl-NHC Hydrotris(pyrazolyl)borate Ruthenium(II) Complexes: Synthesis, Characterization, and Reactivity with Small Molecules. Inorg. Chem. 2013, 52, 4396-4410.

(24) Benítez Junquera, L.; Puerta, M. C.; Valerga, P. R-Allyl Nickel(II) Complexes with Chelating N-Heterocyclic Carbenes: Synthesis, Structural Characterization, and Catalytic Activity. Organometallics 2012, 31, 2175-2183.

(25) Albrecht, M.; Miecznikowski, J. R.; Samuel, A.; Faller, J. W.; Crabtree, R. H. Chelated Iridium(III) Bis-carbene Complexes as AirStable Catalysts for Transfer Hydrogenation. Organometallics 2002, 21, 3596-3604.

(26) Poyatos, M.; Mas-Marza, E.; Sanau, M.; Peris, E. Synthesis and Reactivity of New Chelate-N-Heterocyclic Biscarbene Complexes of Ruthenium. Inorg. Chem. 2004, 43, 1793-1798.

(27) (a) Tubaro, C.; Bertinazzo, D.; Monticelli, M.; Saoncella, O.; Volpe, A.; Basato, M.; Badocco, D.; Pastore, P.; Graiff, C.; Venzo, A. Synthesis and Reactivity of Cationic Bis(N-Heterocyclic Dicarbene) Ruthenium(II) Complexes. Eur. J. Inorg. Chem. 2014, 2014, 15241532. (b) Lai, Y.-B.; Lee, C.-S.; Lin, W.-J.; Naziruddin, A. R.; Hwang, W.-S. Bis-chelate $\mathrm{N}$-heterocyclic tetracarbene $\mathrm{Ru}(\mathrm{II})$ complexes: Synthesis, structure, and catalytic activity toward transfer hydrogenation of ketones. Polyhedron 2013, 53, 243-248.

(28) (a) Hillier, A. C.; Sommer, W. J.; Yong, B. S.; Petersen, J. L.; Cavallo, L.; Nolan, S. P. A Combined Experimental and Theoretical Study Examining the Binding of N-Heterocyclic Carbenes (NHC) to the $\mathrm{Cp} * \mathrm{RuCl}\left(\mathrm{Cp}^{*}=\eta^{5}-\mathrm{C}_{5} \mathrm{Me}_{5}\right)$ Moiety: Insight into Stereoelectronic Differences between Unsaturated and Saturated NHC Ligands. Organometallics 2003, 22 (21), 4322-4326. (b) Huang, J.; Stevens, E. D.; Nolan, S. P.; Petersen, J. L. Olefin Metathesis-Active Ruthenium Complexes Bearing a Nucleophilic Carbene Ligand. J. Am. Chem. Soc. 1999, 121, 2674-2678. (c) Jafarpour, L.; Nolan, S. P. Transition-metal systems bearing a nucleophilic carbene ancillary ligand: from thermochemistry to catalysis. Adv. Organomet. Chem. 2000, 46, 181-222.

(29) Aneetha, H.; Jimenez-Tenorio, M.; Puerta, M. C.; Valerga, P.; Mereiter, K. Bridging and Terminal Half-Sandwich Ruthenium Dinitrogen Complexes and Related Derivatives: A Structural Study. Organometallics 2002, 21, 628-635.

(30) (a) Tanabe, Y.; Kuriyama, S.; Arashiba, K.; Nakajima, K.; Nishibayashi, Y. Synthesis and Reactivity of Ruthenium Complexes Bearing Arsenic-Containing Arsenic-Nitrogen-Arsenic-Type Pincer Ligand. Organometallics 2014, 33, 5295-5300. (b) Bennett, M. A.; Byrnes, M. J.; Chung, G.; Edwards, A. J.; Willis, A. C. Bis(acetylacetonato)ruthenium(II) complexes containing bulky tertiary phosphines. Formation and redox behaviour of $\mathrm{Ru}(\mathrm{acac})_{2}\left(\mathrm{PR}_{3}\right)(\mathrm{R}=$ $\left.{ }^{i} \mathrm{Pr}, \mathrm{Cy}\right)$ complexes with ethene, carbon monoxide, and bridging dinitrogen. Inorg. Chim. Acta 2005, 358, 1692-1708. (c) Zhang, J.; Gandelman, M.; Shimon, L. J. W.; Rozenberg, H.; Milstein, D. Electron-Rich, Bulky Ruthenium PNP-Type Complexes. Acceptorless Catalytic Alcohol Dehydrogenation. Organometallics 2004, 23, 40264033.

(31) Ghosh, K.; Kumar, R.; Kumar, S.; Meena, J. S. Syntheses, structures and properties of ruthenium complexes of tridentate ligands: isolation and characterization of a rare example of ruthenium nitrosyl complex containing $\{\mathrm{RuNO}\}_{5}$ moiety. Dalton 2013, 42, 13444-13452.

(32) Cheng, Y.; Sun, J.-F.; Yang, H.-L.; Xu, H.-J.; Li, Y.-Z.; Chen, X.T.; Xue, Z.-L. Syntheses, Structures, and Catalytic Properties of Ruthenium(II) Nitrosyl Complexes with Pyridine-Functionalized NHeterocyclic Carbenes. Organometallics 2009, 28, 819-823.

(33) Jimenez-Tenorio, M.; Palacios, M. D.; Puerta, M. C.; Valerga, P. Half-Sandwich Hydride Complexes of Ruthenium with Bidentate Phosphinoamine Ligands: Proton-Transfer Reactions to $\left[\left(\mathrm{C}_{5} \mathrm{R}_{5}\right)\right.$ $\mathrm{RuH}(\mathrm{L})][\mathrm{R}=\mathrm{H}, \mathrm{Me} ; \mathrm{L}=$ dippae, $(R, R)$-dippach]. Inorg. Chem. 2007, 46, 1001-1012 and references therein.

(34) (a) Mala, D.; Jagirdar, B. R.; Patil, Y. P.; Nethaji, M. Temperature-dependent elongation of the $\mathrm{H}-\mathrm{H}$ bond in dihydrogen complexes of $\mathrm{Ru}$ (II) bearing an NHC ligand: Effect of the NHC and trans ligands. Inorg. Chim. Acta 2018, 483, 411-424. (b) Mala, D.; Jagirdar, B. R.; Patil, Y. P.; Nethaji, M. Homobimetallic hydride and dihydrogen complexes of ruthenium bearing $\mathrm{N}$-heterocyclic carbene ligands. J. Organomet. Chem. 2017, 830, 203-211. (c) Riddlestone, I. M.; Rajabi, N. A.; Lowe, J. P.; Mahon, M. F.; Macgregor, S. A.; Whittlesey, M. K. Activation of $\mathrm{H}_{2}$ over the $\mathrm{Ru}-\mathrm{Zn}$ Bond in the Transition Metal-Lewis Acid Heterobimetallic Species [Ru$\left.(\mathrm{IPr})_{2}(\mathrm{CO}) \mathrm{ZnEt}\right]^{+}$. J. Am. Chem. Soc. 2016, 138, 11081-11084. (d) Burling, S.; Häller, L. J. L.; Mas-Marzá, E.; Moreno, A.; Macgregor, S. A.; Mahon, M. F.; Pregosin, P. S.; Whittlesey, M. K. The Influence of $\mathrm{N}$-Heterocyclic Carbenes (NHC) on the Reactivity of $\left[\mathrm{Ru}(\mathrm{NHC})_{4} \mathrm{H}\right]^{+}$With $\mathrm{H}_{2}, \mathrm{~N}_{2}, \mathrm{CO}$ and $\mathrm{O}_{2}$. Chem. - Eur. J. 2009, 15, 10912-10923. (e) Giunta, D.; Hölscher, M.; Lehmann, C. W.; Mynott, R.; Wirtz, C.; Leitner, W. Room Temperature Activation of Aromatic $\mathrm{C}-\mathrm{H}$ Bonds by Non-Classical Ruthenium Hydride Complexes Containing Carbene Ligands. Adv. Synth. Catal. 2003, $345,1139-1145$.

(35) Macías-Arce, I.; Puerta, M. C.; Valerga, P. Half-Sandwich Benzylidene Ruthenium Complexes Bearing Phosphanyl-Pyridine Ligands: Reactivity towards Nucleophiles and Electrophiles. Eur. J. Inorg. Chem. 2010, 2010, 1767-1776.

(36) Singh, V. K.; Puerta, M. C.; Valerga, P. One pot synthesis of a $\mathrm{TpRu}$ carbene: Formation and structural characterization of neutral alkylidene complex $\left[\mathrm{TpRu}(=\mathrm{CHPh})\left(\mathrm{PMe}^{i} \mathrm{Pr}_{2}\right) \mathrm{Cl}\right]$. Inorg. Chim. Acta 2009, 362, 3857-3859.

(37) Guerbet, M. C. R. Condensation de l'alcool isopropylique avec son dérivé sodé; formation du méthylisobutylcarbinol et du diméthyl2.4-heptanol-6. C. R. Acad. Sci. 1909, 149, 129-132.

(38) (a) Makarov, I. S.; Madsen, R. Ruthenium-Catalyzed SelfCoupling of Primary and Secondary Alcohols with the Liberation of Dihydrogen. J. Org. Chem. 2013, 78, 6593-6593. (b) Obora, Y. Recent Advances in $\alpha$-Alkylation Reactions using Alcohols with Hydrogen Borrowing Methodologies. ACS Catal. 2014, 4, 39723981. (c) Bai, W.; Jia, G. Ruthenium-catalyzed $\beta$-alkylation of secondary alcohols with primary alcohols. Inorg. Chim. Acta 2015, 431, 234-241. (d) Chakrabarti, K.; Paul, B.; Maji, M.; Chandra Roy, B.; Shee, S.; Kundu, S. Bifunctional Ru(ii) complex catalysed carboncarbon bond formation: an eco-friendly hydrogen borrowing strategy. Org. Biomol. Chem. 2016, 14, 10988-10997. (e) Ng, T. W.; Liao, G.; Lau, K. K.; Pan, H.-J.; Zhao, Y. Room-Temperature Guerbet Reaction with Unprecedented Catalytic Efficiency and Enantioselectivity. Angew. Chem., Int. Ed. 2020, 59, 11384-11389.

(39) Zhang, C.; Zhao, J.-P.; Hu, B.; Shi, J.; Chen, D. RutheniumCatalyzed $\beta$-Alkylation of Secondary Alcohols and $\alpha$-Alkylation of Ketones via Borrowing Hydrogen: Dramatic Influence of the Pendant N-Heterocycle. Organometallics 2019, 38 (3), 654-664.

(40) (a) Cheng, Y.; Xu, H.; Sun, J.; Li, Y.; Chen, X.; Xue, Z. Synthesis, structures and catalytic activities of ruthenium(II) carbonyl chloride complexes containing pyridine-functionalised $\mathrm{N}$-heterocyclic carbenes. Dalton Trans. 2009, 7132-7140. (b) Zeng, F.; Yu, Z. Ruthenium(II) Complexes Bearing a Pyridyl-Supported Pyrazolyl-NHeterocyclic Carbene (NNC) Ligand and Their Catalytic Activity in the Transfer Hydrogenation of Ketones. Organometallics 2008, 27, 6025-6028. 
(41) Pontes da Costa, A.; Viciano, M.; Sanaú, M.; Merino, S.; Tejeda, J.; Peris, E.; Royo, B. First Cp*-Functionalized NHeterocyclic Carbene and Its Coordination to Iridium. Study of the Catalytic Properties. Organometallics 2008, 27, 1305-1309.

(42) Oshima, N.; Suzuki, H.; Moro-oka, Y. Synthesis and some reactions of dichloro(pentamethylcyclopentadienyl)ruthenium(III) oligomer. Chem. Lett. 1984, 13, 1161-1164.

(43) SAINT: Area-Detector Integration Software, version 6.02A; Siemens Industrial Automation, Inc.: Madison, WI, 1995.

(44) Sheldrick, G. M. SADABS, version 2001; University of Göttingen: Göttingen, Germany, 2001.

(45) (a) Sheldrick, G. M. SHELXTL, Crystal Structure Analysis Package, version 6.10; Bruker AXS: Madison, WI, 2000. (b) Sheldrick, G. M. Crystal structure refinement with SHELXL. Acta Crystallogr., Sect. A: Found. Crystallogr. 2008, 64, 112-122.

(46) Farrugia, L. J. ORTEP-3 for Windows, version 1.076. J. Appl. Crystallogr. 1997, 30, 565. 